\title{
Signatures of seaway closures and founder dispersal in the phylogeny of a circumglobally distributed seahorse lineage Peter R Teske* ${ }^{*}, 2$, Healy Hamilton ${ }^{3}$, Conrad A Matthee ${ }^{2}$ and Nigel P Barker ${ }^{1}$
}

Address: ${ }^{1}$ Molecular Ecology and Systematics Group, Botany Department, Rhodes University, 6140 Grahamstown, South Africa, ${ }^{2}$ Evolutionary Genomics Group, Department of Botany and Zoology, Stellenbosch University, Private Bag X1, Matieland 7602, South Africa and ${ }^{3}$ Research Division, California Academy of Sciences, 875 Howard St., San Francisco, CA 94103, USA

Email: Peter R Teske* - Peter.Teske@bio.mq.edu.au; Healy Hamilton - hhamilton@calacademy.org; Conrad A Matthee - cam@sun.ac.za; Nigel P Barker - N.Barker@ru.ac.za

* Corresponding author

Published: 15 August 2007

BMC Evolutionary Biology 2007, 7:138 doi:10.1 186/147/-2148-7-138
Received: 20 December 2006

Accepted: 15 August 2007

This article is available from: http://www.biomedcentral.com//47I-2/48/7//38

(C) 2007 Teske et al; licensee BioMed Central Ltd.

This is an Open Access article distributed under the terms of the Creative Commons Attribution License (http://creativecommons.org/licenses/by/2.0), which permits unrestricted use, distribution, and reproduction in any medium, provided the original work is properly cited.

\begin{abstract}
Background: The importance of vicariance events on the establishment of phylogeographic patterns in the marine environment is well documented, and generally accepted as an important cause of cladogenesis. Founder dispersal (i.e. long-distance dispersal followed by founder effect speciation) is also frequently invoked as a cause of genetic divergence among lineages, but its role has long been challenged by vicariance biogeographers. Founder dispersal is likely to be common in species that colonize remote habitats by means of rafting (e.g. seahorses), as long-distance dispersal events are likely to be rare and subsequent additional recruitment from the source habitat is unlikely. In the present study, the relative importance of vicariance and founder dispersal as causes of cladogenesis in a circumglobally distributed seahorse lineage was investigated using molecular dating. A phylogeny was reconstructed using sequence data from mitochondrial and nuclear markers, and the well-documented closure of the Central American seaway was used as a primary calibration point to test whether other bifurcations in the phylogeny could also have been the result of vicariance events. The feasibility of three other vicariance events was explored: a) the closure of the Indonesian Seaway, resulting in sister lineages associated with the Indian Ocean and West Pacific, respectively; b) the closure of the Tethyan Seaway, resulting in sister lineages associated with the Indo-Pacific and Atlantic Ocean, respectively, and c) continental break-up during the Mesozoic followed by spreading of the Atlantic Ocean, resulting in pairs of lineages with amphi-Atlantic distribution patterns.
\end{abstract}

Results: Comparisons of pairwise genetic distances among the seahorse species hypothesized to have diverged as a result of the closure of the Central American Seaway with those of published teleost sequences having the same distribution patterns show that the seahorses were among the last to diverge. This suggests that their cladogenesis was associated with the final closure of this seaway. Although two other divergence events in the phylogeny could potentially have arisen as a result of the closures of the Indonesian and Tethyan seaways, respectively, the timing of the majority of bifurcations in the phylogeny differed significantly from the dates of vicariance events suggested in the literature. Moreover, several divergence events that resulted in the same distribution patterns of lineages at different positions in the phylogeny did not occur contemporaneously. For that reason, they cannot be the result of the same vicariance events, a result that is independent of molecular dating.

Conclusion: Interpretations of the cladogenetic events in the seahorse phylogeny based purely on vicariance biogeographic hypotheses are problematic. We conclude that the evolution of the circumglobally distributed seahorse lineage was strongly influenced by founder dispersal, and suggest that this mode of speciation may be particularly important in marine organisms that lack a pelagic dispersal phase and instead disperse by means of rafting. 


\section{Background}

Bifurcations in a phylogeny can be explained by two modes of allopatric speciation: vicariance [1] (the establishment of a dispersal barrier separating regional units of a previously continuously distributed species) and founder dispersal [2-4] (long-distance dispersal of a small number of individuals from a source population followed by founder effect speciation in the absence of additional gene flow). Although most biogeographers consider both vicariance and founder dispersal to be important causes of cladogenesis, speciation as a result of dispersal is sometimes rejected or considered irrelevant noise on the basis of its sporadic nature. It is argued that in the majority of cases in which dispersal has been invoked, it is considered to have affected only individual species rather than the entire fauna of a particular region [5].

Cladogenesis as a result of founder dispersal may be more important in seahorses (genus Hippocampus) than in many other marine organisms studied to date, because of their life-histories and means of dispersal [6]. Seahorses use a prehensile tail to hold on to objects that may serve as rafts, such as floating seaweed $[7,8]$. As macrobenthic prey tends to be abundant on these rafts [9], displaced seahorses are likely to survive for a considerable amount of time. In most species, pregnant male seahorses can have brood sizes of up to 100-300 individuals [10], suggesting that a sufficiently large number of closely related individuals may arrive simultaneously at a new habitat to establish themselves. As additional recruitment from the source population is unlikely (because long-distance dispersal along the same route is likely to be rare), lack of gene flow coupled with genetic drift may eventually result in speciation. The combination of seahorses rarely dispersing through the open ocean, but surviving well in it and having a high potential of successfully founding new populations, makes them interesting models for studying the relative importance of vicariance and founder dispersal in marine organisms that disperse by means of rafting.

\section{Molecular dating of marine organisms' phylogenies}

Recent advances in the field of model-based analyses have considerably improved the level of confidence in time estimates obtained from molecular data [11]. Variations in evolutionary rates can be accounted for, and uncertainties with regard to calibration points can be incorporated by specifying upper and/or lower limits for a particular divergence event. Nonetheless, in recent reviews of molecular biogeography and molecular dating, Heads $[12,13]$ criticized studies whose results supported cladogenesis as a result of founder dispersal on the basis of questionable molecular dating. Molecular dating can be performed using three methods of calibration: a) dating of the root of the phylogeny of a particular taxon by using the age of the taxon's oldest known fossil; b) dating of the age of a taxon present on a volcanic island by using the age of the island and c) dating of the cladogenic event that gave rise to two lineages present on either side of a geological barrier by using the time when the barrier formed. Heads [13] rejected the first two methods for the following reasons. Firstly, new fossils are often found that are considerably older than the previously known oldest fossil of a particular taxon, and it is thus impossible to be certain whether the oldest fossil of a particular taxon has indeed been found. The method can be considered particularly problematic in the case of shallow water marine organisms, whose fossil record is often fragmented [14,15]. Seahorses present a case in point, because their fossils are known from only two sites in the northern Mediterranean $[16,17]$. Secondly, dating by means of the age of volcanic islands can be problematic because such islands are located on subduction zones where new islands are created and old ones disappear continuously, suggesting that an extant species occurring on a volcanic island may be older than its habitat.

\section{Molecular dating using vicariance events}

Two major types of vicariance events are potentially useful to calibrate molecular clocks of marine organisms: seaway closures and continental break-up. The best documented vicariance event that impacted on the biogeography of marine species is the closure of the Central American Seaway. The rising of the Isthmus of Panama during the Pliocene isolated the tropical western Atlantic and eastern Pacific oceans [18-20] and resulted in the divergence of formerly continuously distributed species, many of which have remained morphologically similar and are thus readily recognizable as sister taxa. For that reason, the majority of studies on marine species have used the closure of the Central American Seaway as a calibration point [21-23]. However, the utility of such geminate species for calibrating molecular clocks can be nonetheless be problematic. Firstly, some of the species that have been identified as sister taxa may have diverged prior to the final closure of the Central American Seaway (3.1 - 3.5 mya [19]), which results in overestimates of mutation rates [22-24]. Such earlier divergence may have been the result of the oceanographic changes associated with the rising of the isthmus before final seaway closure, or originations resulting from changes in carbonate levels as a result of seaway constriction $[25,26]$. Secondly, incomplete taxon sampling may result in the wrong species being identified as sister taxa [27].

Few studies on marine organisms have sampled lineages with circumglobal distributions $[28,29]$. For these, additional seaway closures could be used as calibration points, which may result in greater precision of molecular dating. The closure of the Tethyan Seaway, which once connected the Atlantic Ocean with the Indo-Pacific via the Mediter- 
Table I: Cytochrome $b$ and I6S rRNA sequences of various teleost lineages whose geographic distributions may have resulted from the closures of the Central American, Indonesian and Tethyan seaways, or from continental break-up and spreading of the Atlantic Ocean. Pairwise Kimura 2-Parameter distances between lineages were plotted in Fig. 3.

\begin{tabular}{|c|c|c|c|c|c|}
\hline Molecular marker & Letter in Fig. 3 & Lineage I & Lineage 2 & Accession numbers & Reference \\
\hline \multirow[t]{24}{*}{ Cytochrome $b$} & $A$ & Selene peruviana & S. setapinnis & AF363743/AF363745 & 118 \\
\hline & B & $\begin{array}{l}\text { Hippocampus ingens/ } \\
\text { fisheri }\end{array}$ & H. reidi/algiricus & (see Table 3) & (this study) \\
\hline & C & Merluccius albidus & M. productus/gayi & $\begin{array}{l}\text { AY821666/AY821670/ } \\
\text { AY821771 }\end{array}$ & Perez et al., unpubl. \\
\hline & $\mathrm{D}$ & Aulostomus chinensis & A. maculatus & $\begin{array}{l}\text { AF327455/ } \\
\text { AF327456AY786433 }\end{array}$ & 28 \\
\hline & $E$ & Centropomus viridis & C. undecimalis/poeyi & AF018599-AF018629 & 23 \\
\hline & $\mathrm{F}$ & Ophioblennius atlanticus & O. steindachneri & AF323030-AF323038 & 72 \\
\hline & G & Strongylura marina & S. exilis & $\frac{\mathrm{AF} 231641 / \mathrm{AF} 231647 /}{\mathrm{AF} 231653 / \mathrm{AF} 231654}$ & 97 \\
\hline & $\mathrm{H}$ & $\begin{array}{l}\text { Chaetodon } \\
\text { paucifasciatus }\end{array}$ & $\begin{array}{l}\text { C. rhombochaetodon } \\
\text { complex }\end{array}$ & $\underline{\mathrm{U} 23585}-\underline{\mathrm{U} 23733}$ & 39 \\
\hline & 1 & $\begin{array}{l}\text { Chaetodon } \\
\text { guttatissimus }\end{array}$ & $\begin{array}{l}\text { C. multicinctus/ } \\
\text { punctatofasciatus }\end{array}$ & $\underline{U} 23585-\underline{U 23733}$ & 39 \\
\hline & J & $\begin{array}{l}\text { Hippocampus kuda } \\
\text { (Indian Ocean) }\end{array}$ & $\begin{array}{l}\text { H. kuda (Pacific } \\
\text { Ocean) }\end{array}$ & (see Table 3) & (this study) \\
\hline & $\mathrm{K}$ & Pterois miles & P. volitans & A]429419-A]429433 & 42 \\
\hline & $L$ & Hippocampus capensis & $\begin{array}{l}\text { H. ingens/fisheri/reidi/ } \\
\text { algiricus }\end{array}$ & (see Table 3) & (this study) \\
\hline & M & $\begin{array}{l}\text { Hippocampus } \\
\text { guttulatus/zosterae/ } \\
\text { erectus/hippocampus }\end{array}$ & $\begin{array}{l}\text { H. spinosissimus/ } \\
\text { kelloggi/kuda/fuscus/ } \\
\text { capensis/reidi/algiricus/ } \\
\text { ingens/fisheri }\end{array}$ & (see Table 3) & (this study) \\
\hline & $\mathrm{N}$ & Lethrinus atlanticus & $\begin{array}{l}\text { Lethrinus Indo-Pacific } \\
\text { lineage }\end{array}$ & $\underline{A F 81225 I}-\underline{A F 812271}$ & 119 \\
\hline & O & $\begin{array}{l}\text { Thalassoma (Atlantic } \\
\text { Ocean lineage) }\end{array}$ & $\begin{array}{l}\text { Thalassoma (Indo- } \\
\text { Pacific lineage)/ } \\
\text { Gomphosus }\end{array}$ & $\underline{\mathrm{A} Y 328857-\underline{\mathrm{A} Y 328885}}$ & 120 \\
\hline & $P$ & $\begin{array}{l}\text { Albula vulpes/ } \\
\text { glossodonta/A/B/C/E }\end{array}$ & A. neoguinaica/D & $\underline{A F 311751-A F 31171}$ & 121 \\
\hline & Q & Hippocampus reidi & H. algiricus & (see Table 3) & (this study) \\
\hline & $\mathrm{R}$ & $\begin{array}{l}\text { Albula sp. B (West } \\
\text { Atlantic) }\end{array}$ & $\begin{array}{l}\text { Albula sp. B. (East } \\
\text { Atlantic) }\end{array}$ & 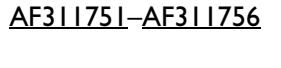 & 121 \\
\hline & $\mathrm{S}$ & Strongylura timucu & S. senegalensis & $\underline{A F 231653 / A F 231654}$ & 97 \\
\hline & $\mathrm{T}$ & Hippocampus erectus & H. hippocampus & (see Table 3) & (this study) \\
\hline & $\cup$ & $\begin{array}{l}\text { Sparisoma axillare/ } \\
\text { rubripinne (West } \\
\text { Atlantic) }\end{array}$ & $\begin{array}{l}\text { S. rubripinne (East } \\
\text { Atlantic) }\end{array}$ & $\frac{\text { DQ457034- }}{\text { DQ457036 }}$ & 98 \\
\hline & $\vee$ & $\begin{array}{l}\text { Hippocampus } \\
\text { guttulatus }\end{array}$ & $\begin{array}{l}\text { H. zosterae/erectus/ } \\
\text { hippocampus }\end{array}$ & (see Table 3) & (this study) \\
\hline & w & Nicholsina usta usta & N. usta collettei & $\begin{array}{l}\text { DQ457022/ } \\
\text { DQ457023 }\end{array}$ & 98 \\
\hline & $\mathrm{x}$ & $\begin{array}{l}\text { Thalassoma } \\
\text { norohanum/bifasciatum }\end{array}$ & $\begin{array}{l}\text { T. newtoni/ } \\
\text { sancthelenae/ } \\
\text { ascensionis/pavo }\end{array}$ & $\begin{array}{l}\text { AY32886I/AY328863/ } \\
\text { AY328876/AY328877/ } \\
\text { AY328882 }\end{array}$ & 120 \\
\hline \multirow[t]{8}{*}{ I6S rRNA } & A & Holocanthus passer & H. bermudensis & AY530857/AY530867 & 61 \\
\hline & B & $\begin{array}{l}\text { Hippocampus ingens/ } \\
\text { fisheri }\end{array}$ & H. reidi/algiricus & (see Table 3) & (this study) \\
\hline & C & $\begin{array}{l}\text { Pomacantus parul } \\
\text { arcuatus }\end{array}$ & P. zonipectus & $\frac{\text { AY530852/AY530868/ }}{\text { AY530874 }}$ & 61 \\
\hline & $\mathrm{D}$ & Centropomus ensiferus & C. robalito & $\underline{\text { U85008/U850II }}$ & 23 \\
\hline & $E$ & Centropomus viridis & C. undecimalis/poeyi & $\underline{\mathrm{U} 85012 / \mathrm{U} 85013 /}$ & 23 \\
\hline & $\mathrm{F}$ & Strongylura exilis & S. marina & $\underline{A F 231515 / A F 231521}$ & 86 \\
\hline & G & Aulostomus chinensis & A. maculatus & AY141423/AY538973 & 122,123 \\
\hline & $\mathrm{H}$ & $\begin{array}{l}\text { Hippocampus kuda } \\
\text { (Indian Ocean) }\end{array}$ & $\begin{array}{l}\text { H. kuda (Pacific } \\
\text { Ocean) }\end{array}$ & (see Table 3) & (this study) \\
\hline
\end{tabular}


Table I: Cytochrome $b$ and I6S rRNA sequences of various teleost lineages whose geographic distributions may have resulted from the closures of the Central American, Indonesian and Tethyan seaways, or from continental break-up and spreading of the Atlantic Ocean. Pairwise Kimura 2-Parameter distances between lineages were plotted in Fig. 3. (Continued)

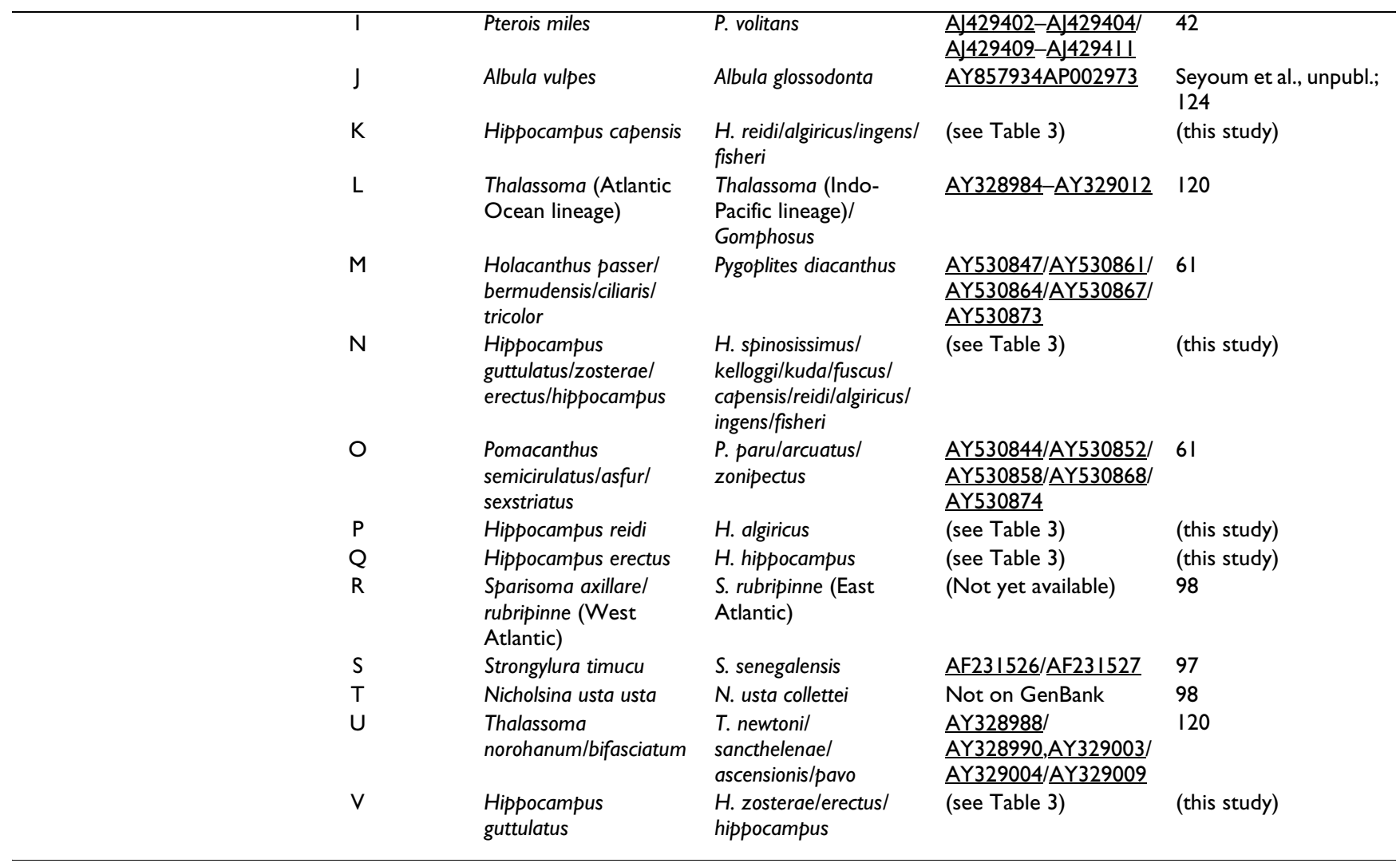

ranean, has been used comparatively rarely to date phylogenies [30,31]. The reason for this may be that the occurrence of both tectonism and climate change (resulting in cyclic fluctuations in the sea level) makes dating of the vicariance event that severed the link between the Mediterranean and the Indo-Pacific problematic, and the exact date of this seaway's final closure is disputed. Drooger [32] considered it to have taken place during the Late Oligocene (23.8 - 28.5 mya), Adams et al. [33,34] suggested a Late Early Miocene closure (18.4 - 20.5 mya), and Rögl and Steininger [35,36] argued for a temporary re-opening during the Middle Miocene (14.8 - 18.4 mya) followed by complete closure 11.2 - 14.8 mya. Adams et al. [37] rejected the evidence for both the Late Oligocene and Middle Miocene closures on the basis of questionable dating. The Middle Miocene date for a temporary re-opening of the seaway $[35,36]$ is nevertheless widely accepted, although some marine organisms from the Indian Ocean do not seem to have dispersed through the Tethyan seaway during this time [38].

Recent genetic work identified the existence of marine sibling species associated with the Indian and Pacific Oceans, respectively, whose distributions sometimes overlap in Indonesia [6,39-43]. The divergence between some of these has been attributed to temporary closure events of the Indonesian Throughflow, which presently connects the Indian and Pacific oceans. Complete and long-lasting closure events were estimated to have taken place during the Middle Miocene (15 - 17 mya [44]) and during the Late Miocene (7.5 - 9.9 mya [45] or 7.0 - 9.5 mya [46]). A further closure of the Indonesian Seaway took place during the Pliocene ( 3 - 4 mya [47]). Lastly, tectonic uplifts and lowered sea level during Pleistocene glaciations resulted in restricted exchange between Indian Ocean and West Pacific Ocean faunas [48,49].

In addition to distribution patterns that may have arisen as a result of the three seaway closure events, the presence of sister species on either side of the Atlantic Ocean could be interpreted as being the result of continental break-up. Rosen [50] attributed such patterns to sea-floor spreading and widening of the Atlantic Ocean, following the separation of Africa and South America no later than approximately 84 mya [51].

\section{The relative importance of vicariance and founder dispersal}

In the present paper, we investigated the relative importance of vicariance and founder dispersal as modes of allo- 


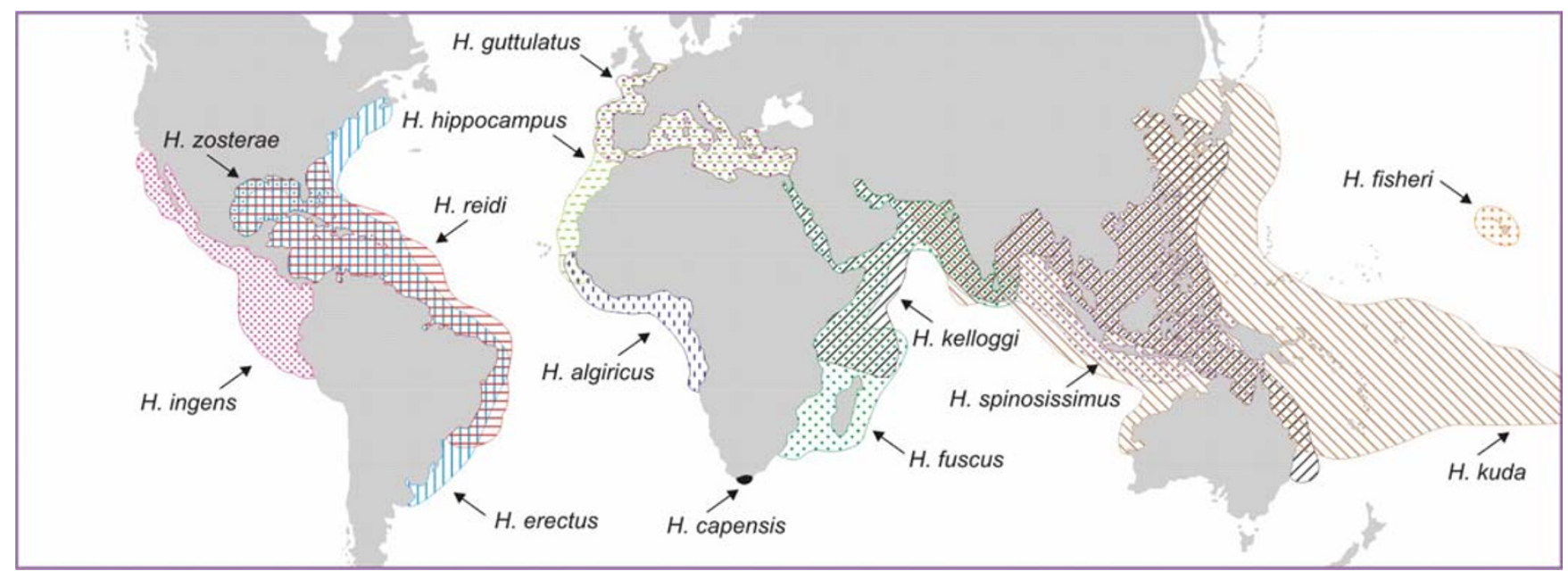

\section{Figure I}

Seahorse distribution ranges. Geographic distributions of species associated with the circumglobally distributed seahorse lineage (after Lourie et al. [6l]).

patric speciation that may have impacted on the phylogeny of a circumglobally distributed seahorse lineage (Fig. 1), while accounting for the abovementioned uncertainties regarding molecular dating of the phylogenies of marine organisms. This particular lineage was chosen because its wide distribution may either indicate ancient vicariance or large-scale dispersal, and because it may have been affected by more than one vicariance event. Exact phylogenetic relationships are not fully understood, but all species associated with this lineage have been identified using molecular methods [52,53], ensuring complete taxon sampling. Other seahorse lineages are less useful for this purpose, because they have more restricted distributions, phylogenetic relationships are comparatively poorly resolved, and a recent increase in species descriptions makes it likely that not all species have yet been identified [52-54].

Without knowledge of divergence times, the distribution patterns of several pairs of lineages within the circumglobal clade could be interpreted as being the result of vicariance. These include Eastern Pacific vs. Atlantic species (whose divergence could be the result of the closure of the Central American Seaway), Indian Ocean vs. West Pacific species (Indonesian Seaway closure), Atlantic vs. IndoPacific species (Tethyan Seaway closure) and amphiAtlantic species pairs (spreading of the Atlantic Ocean).

Vicariance biogeographers have objected to founder dispersal hypotheses because the sporadic nature of such events does not make them falsifiable [55]. Although the establishment of ocean currents has in some cases resulted in repeated directional long-distance dispersal [56,57], whether or not a species becomes established in a new habitat depends considerably on its dispersal abilities and life history characteristics. Even if a large number of species share a pattern resulting from founder dispersal, it is unlikely that they all would have colonized a particular habitat contemporaneously, and molecular dating using founder dispersal is thus less precise than molecular dating using vicariance events. However, if vicariance hypotheses can be rejected, then founder dispersal should be supported by default [5]. In this study, we estimated the ages of divergence events of seahorse lineages with geminate distribution patterns by using the well-documented closure of the Central American Seaway as a primary calibration point. Vicariance biogeographic interpretations of these are challenged if a) divergence time estimates are significantly different from the dates of vicariance events suggested in the literature and b) divergence events in different positions in the phylogeny that have resulted in the same distribution patterns of sister lineages have occurred at different times.

\section{Results \\ Phylogenetic reconstructions}

A maximum likelihood phylogenetic tree reconstructed from sequence data of three mitochondrial and two nuclear markers recovered six major clades that were each associated with a distinct biogeographic region (Fig. 2). A congruent tree was recovered with Bayesian Inference, and most nodes were supported by significant posterior probabilities. The most parsimonious tree, on the other hand, did not recover some of the lineages, but none of the nodes that differed from the other two phylogenies had high support (all jackknife values $<56$ ). When a parsi- 


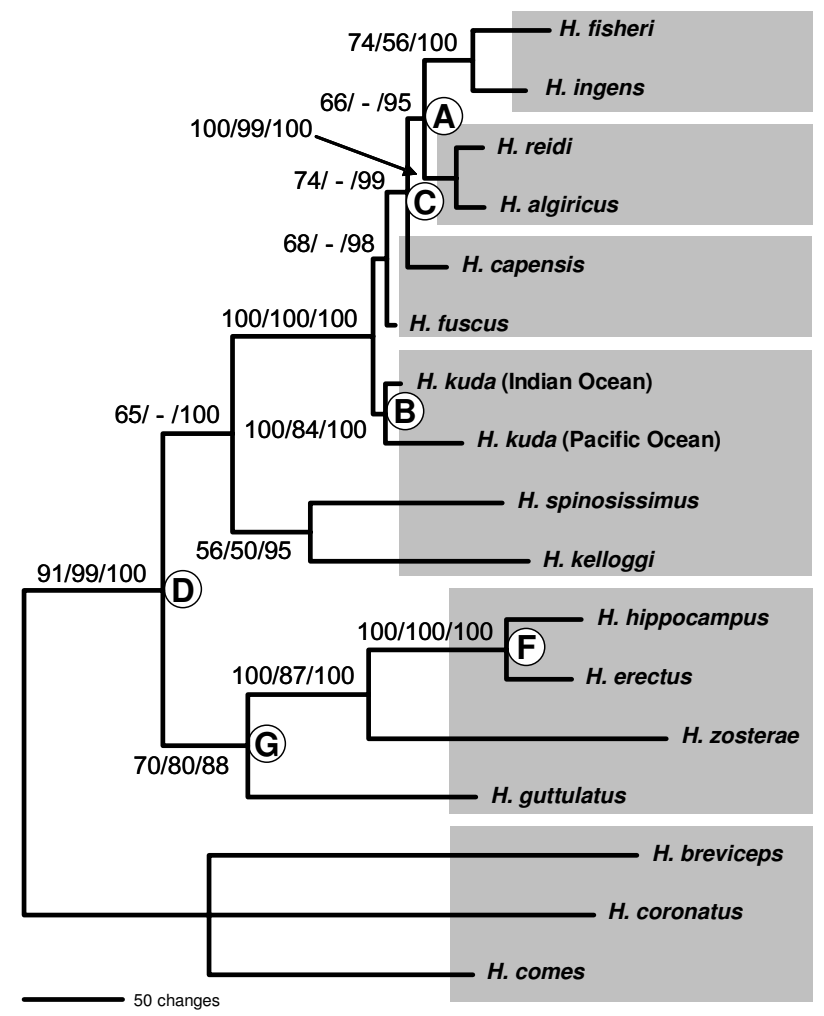

\section{East and Central Pacific}

Atlantic Ocean biome

Western Indian Ocean

Indo-West Pacific

Atlantic Ocean biome

\section{Outgroup}

\section{Figure 2}

Phylogeny of the circumglobal seahorse lineage. The phylogenetic tree with the highest likelihood score reconstructed by means of likelihood ratcheting. The data matrix comprised five partitions: mitochondrial control region, cytochrome $b$ and I6S rRNA, and nuclear S7 intron and Aldolase. Associations of lineages with biogeographic regions are indicated. Nodal support is indicated by three numbers; these represent bootstrap values from maximum likelihood searches, jackknife support from parsimony searches, and posterior probabilities from Bayesian Inference. Hyphens indicate clades that were not recovered using parsimony. White circles indicate divergence events that may have resulted from vicariance events. Letters within these correspond to those in Table 2.

mony tree was constructed using the two most rapidly mutating markers only (control region and cytochrome $b$ ), then node A was also recovered.

The distribution patterns of several lineages in the phylogeny indicate that they could be the result of seaway closures or spreading of the Atlantic Ocean (indicated by letters $A-G)$. In several cases, the same distribution patterns were recovered in different positions in the tree. Firstly, a split into an Atlantic and an Indo-West Pacific lineage was recovered twice. The first event (node D) resulted in a split into an Atlantic Ocean group comprising Hippocampus hippocampus, $H$. erectus, $H$. zosterae and $H$. guttulatus, and a group whose basal split resulted in an
Indo-West Pacific lineage comprising H. spinosissimus and $H$. kelloggi and a lineage comprising all remaining species (present in the Indo-West Pacific, Atlantic Ocean and East/Central Pacific). The fact that Indo-West Pacific species are present in both of the latter lineages suggests that this group may have originated in this region. The second event that resulted in an Atlantic Ocean and an Indo-West Pacific lineage is the split defined by node $\mathrm{C}$, resulting in the divergence of $H$. capensis (western Indian Ocean) and the Atlantic/eastern Pacific group comprising $H$. ingens, $H$. fisheri, $H$. reidi and $H$. algiricus. Amphi-Atlantic distribution patterns were recovered three times, the most basal being a split between the eastern Atlantic $H$. guttulatus and a group including the western Atlantic species $H$. erectus 
Table 2: Divergence time estimates among seahorse lineages whose cladogenesis may have been the result of vicariance events by virtue of the present-day distribution patterns of their species.

\begin{tabular}{|c|c|c|c|c|c|c|}
\hline \multirow[b]{2}{*}{ Calibration range } & \multicolumn{6}{|c|}{ Node } \\
\hline & B & C & $\mathrm{D}$ & E & $\mathrm{F}$ & G \\
\hline \multirow[t]{2}{*}{$3.1-3.5$} & $3.73 \pm 0.29$ & $3.67 \pm 0.42$ & $15.12 \pm 3.46$ & $1.47 \pm 0.53$ & $5.33 \pm 1.79$ & $14.60 \pm 3.37$ \\
\hline & $(2.26-5.84)$ & $(3.18-4.76)$ & $(9.85-23.26)$ & $(0.54-2.6 I)$ & $(2.64-9.47)$ & $(9.53-22.49)$ \\
\hline \multirow[t]{2}{*}{$3.1-4.6$} & $4.26 \pm 1.15$ & $4.16 \pm 0.66$ & $16.60 \pm 4.00$ & $1.66 \pm 0.63$ & $6.01 \pm 2.13$ & $16.05 \pm 3.89$ \\
\hline & $(2.46-6.94)$ & $(3.24-5.70)$ & $(10.50-26.05)$ & $(0.60 \pm 3.04)$ & $(2.89-11.14)$ & $(10.09-25.22)$ \\
\hline \multirow{2}{*}{$3.1-8.5$} & $5.15 \pm 1.92$ & $5.03 \pm 1.50$ & $19.07 \pm 5.76$ & $2.02 \pm 0.94$ & $7.18 \pm 3.07$ & $18.46 \pm 5.63$ \\
\hline & $(2.60-9.98)$ & $(3.27-8.75)$ & $(11.04-33.05)$ & $(0.66-4.31)$ & $(3.07-14.87)$ & $(10.60-32.16)$ \\
\hline
\end{tabular}

Divergence times were estimated using the program MULTIDIVTIME [102] under the assumption that the closure of the Central American Seaway (Node A in Fig. 2) resulted in the divergence of two sister lineages associated with the eastern/central Pacific (Hippocampus ingens and $H$. fisheri) and Atlantic Oceans $(H$. reidi and $H$. algiricus), respectively. Phylogeographic distribution patterns may have been the result of the following vicariance events. Node B (Indian Ocean vs. West Pacific): Closure of the Indonesian Seaway. Nodes C and D (Indo-Pacific vs. Atlantic Ocean): Closure of the Tethyan Seaway. Node E, F and G (amphi-Atlantic distribution patterns): continental break-up and spreading of the Atlantic Ocean. Three possible calibration ranges for the closure of the Central American Seaway were specified. Comparisons of the species affected by this vicariance event with other teleosts having similar distribution patterns (Fig. 3) indicate that the seahorses were among the last to diverge. This suggests that their cladogenesis was associated with the final closure of the seaway, i.e. no earlier than approximately 4.6 mya (a hypothesis that is further supported by the finding that marine organisms in nearshore habitats were among the last species to have diverged as a result of Central American seaway closure $[20,60,61]$ ). Divergence time estimates are indicated as mean \pm S.D. (95\% confidence interval). Suggested dates of vicariance events: Central American Seaway closure: 3.1 - 3.5 mya (assuming that the divergence of the transisthmian seahorse lineages took place when a land bridge formed in Central America [18]); 3.1 - 4.6 (taking into consideration that seahorse divergence may have been affected by the reorganisation of ocean currents associated with the closure of the seaway [24]); 3.I - 8.5 mya (the upper bound being the time when the earliest recorded evolution associated with the closure of the seaway took place in marine corals and foraminiferans [25]); Indonesian Seaway closure: $0.01-1.8$ [47,48]; $3-4$ mya [46]; 7 - 10 mya [44,45]; 15 - 17 mya [43]; Tethyan Seaway closure: II.2 - I4.8 mya [34,35]; I8.4 - 20.5 [36]; 23.8 - 28.5 [3।]; complete separation of the land masses on either side of the Atlantic Ocean: 84 mya [50].

and H. zosterae (node G; this group also includes the eastern Atlantic species H. hippocampus in a derived position), followed by a later amphi-Atlantic split between $H$. erectus and $H$. hippocampus (node F). The divergence between $H$. reidi and $H$. algiricus resulted in a further amphi-Atlantic distribution pattern (node E).

\section{Molecular dating}

To explore the feasibility that the seahorse lineages present on either side of the Isthmus of Panama diverged as a result of Central American Seaway closure, we compared pairwise genetic distances between them with genetic distances between other geminate teleost lineages present on both sides of the Isthmus of Panama (Table 1, Fig. 3). We hypothesized that if the divergence of the seahorse lineages was linked to the final closure of the seaway, then the pairwise distance between them should be among the lowest of all the teleost lineages investigated. Pairwise distances were also calculated for pairs of teleost lineages that could have arisen as a result of the other three vicariance events relevant to the circumglobally distributed seahorse lineage by virtue of their distribution patterns. Using relative rate tests, it was found that only one of the teleost genera whose species have distribution patterns identical to those of the geminate seahorse lineages was characterized by a significantly different rate (Lethrinus vs. Hippocampus cytochrome $b$ : difference in the rate of non-synonymous sites $=-0.031 \pm 0.015$ [S.D.], $p=$
$0.039)$. The rate of $16 \mathrm{~S}$ rRNA of a number of genera could not be compared with the seahorses, because a different portion of this marker had been sequenced. Pairwise distances between these and the seahorses, as well as those of Lethrinus and Albula (used as outgroup) and the seahorses, are nonetheless shown in Fig. 3 and are indicated with asterisks.

Comparisons of mean K2P distances between pairs of seahorse lineages that may have diverged as a result of vicariance events with those of other teleosts having congruent distribution patterns indicate that the seahorse lineages defined by node A in Fig. 2 (Central American Seaway closure) diverged comparatively recently. We considered this to be evidence for a Pliocene divergence of this lineage as a result of the final closure of the Central American Seaway, an event that is considered to have occurred no earlier than 4.6 mya. The mean genetic distance among cytochrome $b$ sequences of the lineage defined by node $B$ (Indonesian Seaway closure) was slightly lower than that of the lineage defined by node $\mathrm{A}$, whereas the genetic distance among 16S rRNA sequences was distinctly lower. K2P distances among control region sequences (not shown) were also slightly lower for Indonesian Seaway divergence than for Central American Seaway divergence (0.036 and 0.043 , respectively), indicating that this event may have taken place during the Late Pliocene or Early Pleistocene. Present-day distribution patterns of several 


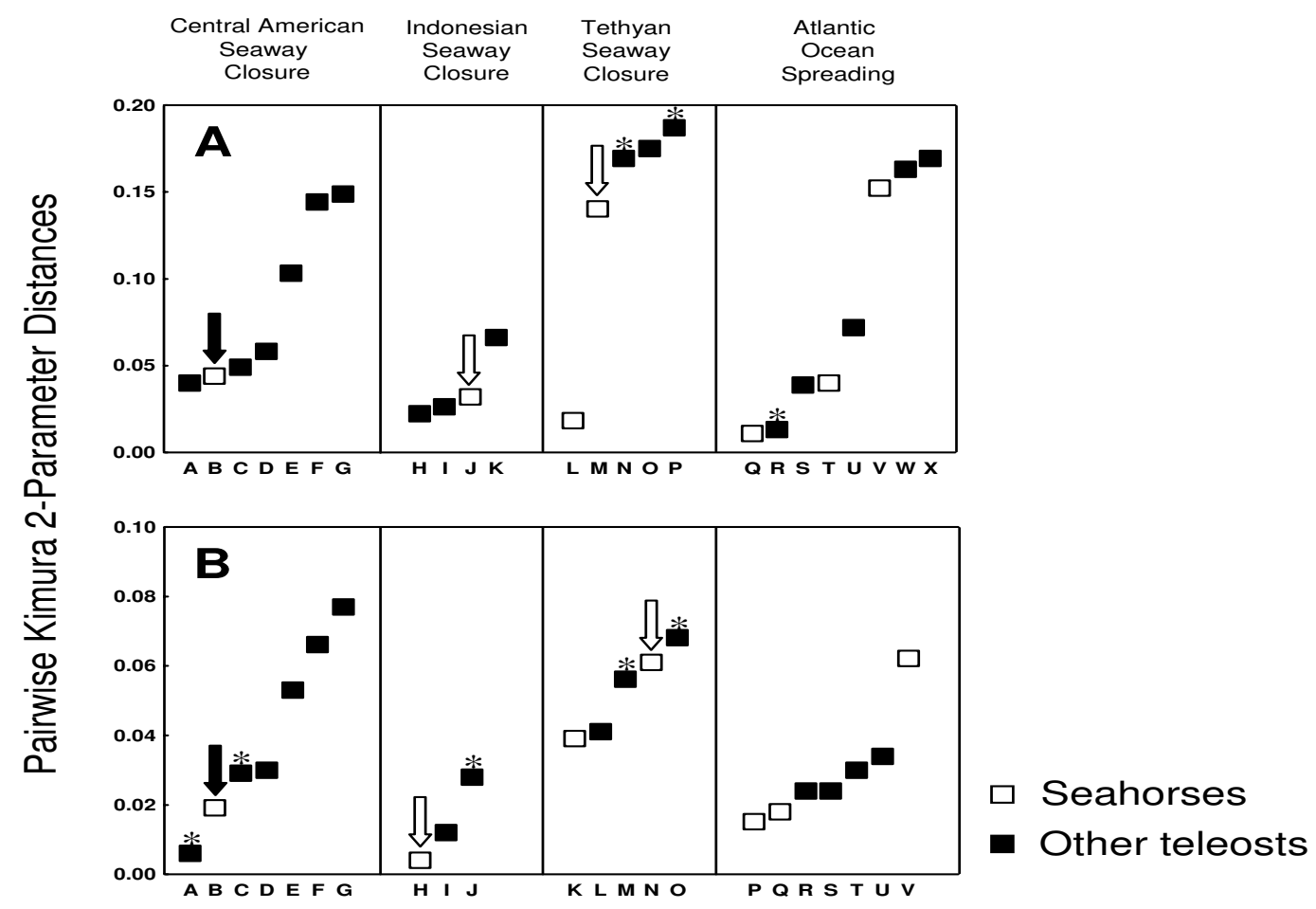

\section{Figure 3}

Genetic distances among geminate teleost species. Pairwise Kimura 2-Parameter distances [104] between lineages of seahorses (white squares) and other teleost species (black squares) whose present-day distribution patterns indicate that they may have diverged as a result of the closures of the Central American, Indonesian, or Tethyan seaways, or as result of continental break-up and spreading of the Atlantic Ocean. A: Cytochrome b sequences; B: I6S rRNA sequences. Letters represent teleost lineages listed in Table I. The black arrow indicates the pairwise distance between the two seahorses lineages hypothesized to have diverged as a result of closure of the Central American Seaway. These lineages were used to estimate divergence times in Table 2. White arrows indicate distances between lineages whose divergence time estimates matched published dates for the closures of the Indonesian and Tethyan seaways (Table 2). Asterisks indicate teleost lineages whose evolutionary rate differed from that of the seahorses $(A: N)$, whose rates were not tested because a different portion of I6S rRNA was sequenced (B: A, C, M, O) or which were used as outgroup in relative rate tests (A: P, R; B: J).

pairs of lineages in the seahorse phylogeny could be interpreted as having resulted from the remaining two vicariance events (two in the case of Tethyan seaway closure and three in the case of continental break-up during the Mesozoic). Mean pairwise K2P distances between these differed considerably, as did distances between other teleost lineages having the same distribution patterns.

Divergence time estimates among seahorse lineages were obtained using a relaxed molecular clock method [58]. When the final date for the closure of the Central Ameri- can seaway (3.1 - 3.5 mya) is accepted as the date when the transisthmian seahorse lineages diverged, based on the considerations in the previous paragraph, then only two divergence estimates of nodes defining species pairs whose distribution patterns indicate that they could have resulted from vicariance events, matched the dates suggested in the literature (Table 2). Firstly, the Indian Ocean and West Pacific lineages of $H$. kuda (node B) were estimated to have diverged $3.73 \pm 0.29$ mya, which indicates that this cladogenic event may have resulted from the closure of the Indonesian Seaway 3 - 4 mya [46]. Secondly, 


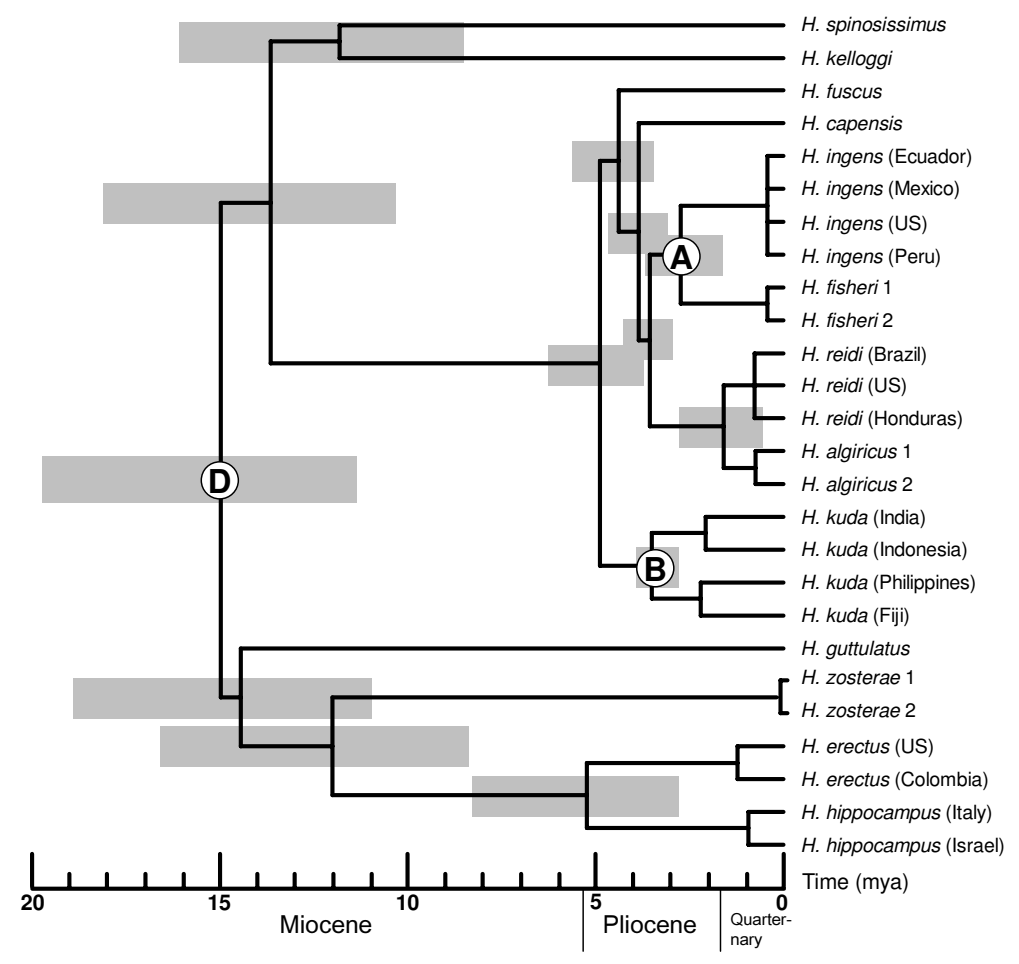

\section{Figure 4}

Chronogram of the circumglobal seahorse clade. An ultrametric tree of the circumglobally distributed seahorse lineage scaled to geological time constructed using the program MULTIDIVTIME [57]. White circles indicate nodes that were used to calibrate the molecular clock; letters within these correspond to the ones used in Fig. 2 . Time intervals used for calibration were: A: 3.I - 4.6 mya; B: 3.0 - 4.0 mya; D: I I.2 - 20.5 mya. Grey bars indicate $95 \%$ confidence intervals of internal nodes.

the species defined by node $\mathrm{D}$ were estimated to have diverged $15.12 \pm 3.46$ mya, which matches the temporary re-opening of the Tethyan seaway during the Middle Miocene (14.8-18.4 mya) followed by complete closure 11.2 - 14.8 mya [34,35]. However, confidence intervals for this estimate are comparatively large $(9.85-23.26$ mya), and the earlier date of $18.4-20.5$ mya [36] must also be considered feasible.

The establishment of the amphi-Atlantic distribution patterns all post-dated 84 mya, irrespective of the calibration range used for the closure of the Central American seaway. This suggests that these were not the result of continental break-up during the Mesozoic. Because of this, and because $95 \%$ confidence intervals of the divergence dates of nodes that have resulted in the same distribution pat- terns did not overlap when a calibration range of $3.1-3.5$ mya was specified for the closure of the Central American Seaway (although some overlap was found when wider calibration ranges were specified, Table 2), interpretations of the seahorses' present-day distribution patterns based exclusively on vicariance biogeographic hypotheses are not well supported.

As divergence time estimates are more precise when multiple calibration points are specified [59], we chose a combination of vicariance events that are likely to have impacted on cladogenesis in the seahorse phylogeny to date all other nodes in the phylogeny. The selection of these was based on the assumption that the divergence event that resulted from the closure of the Central American Seaway occurred no earlier than 4.6 mya, and that the 
closure of the Indonesian Seaway 3 - 4 mya resulted in the divergence of the lineages defined by node $\mathrm{B}$. We also included node $\mathrm{D}$ as a calibration point, assuming that the Atlantic Ocean vs. basally Indo-Pacific distribution of its species resulted from the closure of the Tethyan Seaway. Although the timing of this divergence event is comparatively vague, mean divergence times \pm S.D. estimated when only node A ( $3.1-3.5$ mya) and only node B (3.0 - 4.0 mya) were used as calibration points fell within the ranges of the two most reliable dates for this event suggested in the literature (Node A: 15.12 mya \pm 3.46 mya; Node B: 14.11 mya \pm 3.27 mya; Rögl and Steininger [34,35]: 11.2 - 14.8 mya; Adams et al. [32,33]: $18.4-20.5$ mya). A phylogenetic tree scaled to geological time was constructed by specifying divergence times for the three seaway closure events (Pliocene for the Central American and Indonesian seaways and Late Early to Middle Miocene for the Tethyan Seaway) is characterized by the largest number of divergence events having taken place during the Pliocene (Fig. 4). The 95\% confidence intervals of older divergence events are large compared to most of the more recent events, as we allowed for a wide calibration range for the root node.

\section{Discussion}

Seaway closure events as calibration points

In studies of marine organisms that employ molecular dating, it is common practice to apply the most recent dates suggested in the geological literature to date divergence events considered to have resulted from the closure of a seaway $[30,60,61]$. As the evolutionary histories of geminate species pairs may be more complicated than is generally acknowledged, we avoided overconfidence in calibration points by firstly determining which vicariance events were most likely to have resulted in present-day biogeographic patterns of seahorse species associated with the circumglobal clade, and secondly, by specifying upper and lower bounds for each calibration point to account for uncertainties concerning the exact dates of vicariance events. Comparisons with other teleosts showed that the amphi-Panamaic distribution pattern arose comparatively recently, and is thus likely to have been linked to the final closure of the Central American Seaway. As the four seahorse species affected by the closure of the seaway all occur in shallow water [62], this conclusion is supported by the hypothesis that divergence events among species occurring in the nearshore habitat or in freshwater are linked to the final closure of the Central American Seaway, whereas species with significant marine phases are likely to have diverged earlier $[20,63,64]$. Estimates of the vicariance event that resulted in the basally Indo-Pacific vs. Atlantic Ocean distribution pattern defined by node D (Figs. 2 and 4) were less certain than those of the other two vicariance events. However, our estimates indicate that this basal cladogenic event in the phylogeny is likely to have occurred some time during the Late Early to Middle Miocene, which is supported by geological estimates of the timing of the closure of the Tethyan Seaway [33$36]$.

Comparisons with other pairs of geminate teleost species present on either side of the Isthmus of Panama indicate that K2P distances $\sim 0.05$ for cytochrome $b, \sim 0.045$ for control region (domain II), and $\sim 0.02$ for $16 \mathrm{~S}$ rRNA may indicate that the lineages under investigation are likely to have diverged as a result of the final closure of the Central American Seaway. Assuming a conservative estimate of $3.1-4.6$ mya for the divergence of these lineages, these values correspond to approximately $1-1.5 \%$ (Cytochrome $b$ ), $0.9-1.4 \%$ (control region domain II) and 0.3 - $0.5 \%$ (16S rRNA) sequence divergence per million years, and are thus lower than the commonly used value of $2 \%$ per million years for animal mtDNA [65]. Our results indicate that the closure of the Indonesian Seaway may also be useful for calibrating molecular clocks. In this case, a K2P distance of $\sim 0.03$ for cytochrome $b, \sim 0.036$ for control region, and a distance below 0.02 for 16S rRNA may indicate that the lineages under investigation diverged as a result of Pliocene closure of the seaway.

\section{Causes of other dichotomies in the phylogeny}

Apart from the three seaway closures, there are no obvious vicariance events that could have resulted in any of the other dichotomies. None of the divergence events resulting in sister lineages with amphi-Atlantic distributions could be linked to continental break-up ( 84 mya) and spreading of the Atlantic Ocean on the basis of molecular dating, even when the unlikely upper bound of 8.5 mya was specified for the closure of the Central American Seaway. This date represents the time when the constriction of the seaway and the associated increase in carbonatecontent in southern Caribbean deep-sea sediments resulted in originations in reef corals and carbonate-associated benthic foraminifera, which is unlikely to have affected shallow-water seahorses. A vicariance biogeographic interpretation of these distribution patterns is further weakened by fossil data: the oldest known fossil of the family Syngnathidae (of which seahorses are considered to be one of the most derived genera by virtue of their advanced brood pouch morphology [66]) is less than 50 my old [67].

We suggest that the presence of recently diverged sisterspecies on both sides of the Atlantic Ocean $(H$. erectus [east coast of the Americas] and H. hippocampus [Europe]; $H$. reidi [east coast of the Americas] and $H$. algiricus [West Africa]), is the result of founder dispersal. Divergence time estimates for these two lineages fall into the Late Miocene/ Early Pliocene and Late Pliocene/Pleistocene, respectively. Teske et al. [53] hypothesized that the ancestor of H. hip- 
pocampus colonized Europe from the Americas, as both its sister species $(H$. erectus) and the next basal species $(H$. zosterae) occur in the Caribbean. A Late Miocene/Early Pliocene divergence estimate confirms that this colonization may have been facilitated by an intensification of the Gulf Stream that culminated 3.8 mya $[68,69]$. As this change in ocean circulation was the result of the gradual closing of the Central American Seaway, the founder event that gave rise to $H$. hippocampus is thus likely to be the indirect result of tectonic changes.

The other East Atlantic species, H. algiricus, is also likely to be the product of long-distance dispersal in an eastward direction, as its sister species, $H$. reidi, occurs on the east coast of the Americas, and the next basal lineage comprises eastern Pacific seahorses. The divergence event that gave rise to this amphi-Atlantic geminate species pair took place more recently (Late Pliocene to Pleistocene). There are numerous examples of such recently established amphi-Atlantic distributions in the literature, and in many cases, the lineages in question are morphologically and genetically so similar that they are considered to be single species [70-73]. Even the oldest amphi-Atlantic divergence event in the phylogeny, that between the European species $H$. guttulatus and the lineage comprising basal American species ( $H$. zosterae and $H$. erectus), is unlikely to be the result of vicariance following the expansion of the Atlantic Ocean, as divergence of this lineages was estimated to have occurred during the Miocene. Lastly, vicariance models invoked for the presence of species on Hawai'i suggest that because of the geological history of the Pacific plate, endemic Hawai'ian taxa should have sister taxon relationships with taxa in the Indo-West Pacific $[74,75]$. However, many teleost species present in the Central Pacific have sister taxon relationships with East Pacific species, and there is evidence for sporadic dispersal events in either direction [76]. Our finding that the Hawai'ian seahorse $H$. fisheri is closely associated with American/West African seahorses provides a further example of westward dispersal from the Americas, an event that was estimated to taken place after the closure of the Central American Seaway.

\section{Conclusion}

Since the validation of plate-tectonics theory and the development of cladistic methods, vicariance events have been primarily invoked to explain disjunct species distributions throughout the world. However, improvements in molecular dating techniques have resulted in increased support for recent dispersal hypotheses over more ancient vicariance events, as in many cases, molecular divergences were considered too small to be explained by vicariance [5]. Despite these developments, Heads [12,13] rejected dispersal hypotheses in favor of vicariance hypotheses, and considered studies on the phylogeographic history of cichlid fishes $[77,78]$ (a teleost family of Gondwanan origin that occurs exclusively in freshwater) to be exemplary in terms of their convincing conclusions (and lack of molecular dating). Given that long-distance dispersal between continents is impossible for obligate freshwater fishes, vicariance hypotheses are appropriate to explain observed distribution patterns of freshwater organisms. However, this is completely different in marine organisms, many of which can readily disperse in the oceans over great distances $[27,70,71,76,79]$, and to whom the barrier is thus not absolute. Heads [12] acknowledged that many marine organisms can readily reach far outside their established ranges, but argued that they do not establish themselves because of competition from congeneric vicariants already established in such habitats. Likewise, Briggs [80] suggested that competition may prevent the colonization of high diversity habitats. The "competitive exclusion principle" [81] is now considered to be controversial [82]. Although a number of recent experiments do support the notion that high diversity may increase a community's invasion resistance [83-86], its effect may be difficult to discern from other factors such as predation, inappropriate climate and disease [87]. Nonetheless, the successful establishment of a founder population may be inhibited to some degree by the presence of interspecific competition [88-90], or facilitated by a lack of resource competition (i.e. the existence of an "empty niche" [91]), as the available resources allow the founders to rapidly increase their numbers. This may explain why a) the lineage defined by node A (Fig. 2) is absent from the speciesrich West Pacific, despite the high dispersal potential of its species and b) the colonization of West Africa and Hawai'i (two regions with low seahorse diversity) was possible for $H$. algiricus and $H$. fisheri, respectively. The European species $H$. guttulatus and the more recent arrival H. hippocampus are sympatric, but they do not compete directly because of different microhabitat preferences [92]. The establishment of human-introduced marine species in new habitats is well documented [93-95], and it seems unreasonable to reject the notion that such colonization events may occur naturally, albeit at a lower rate. Both vicariance and founder dispersal thus have to be considered plausible in marine organisms, and our study indicates that molecular dating is a useful tool to determine when a divergence event is likely to have occurred and what may have caused it.

Even if one does not consider genetic differentiation of molecular markers to be at least roughly correlated with time, one must nonetheless concede that the establishment of the same phylogeographic patterns in clades nested within each other in the same phylogeny cannot have occurred simultaneously. Hence, if the divergence of $H$. guttulatus vs. H. zosterae, H. erectus and H. hippocampus was the result of continental break-up and spreading of 
the Atlantic Ocean (vicariance), then the split between $H$. erectus and $H$. hippocampus must have been caused by subsequent long-distance dispersal. This is further supported by the fact that even if the unlikely upper limit of 8.5 mya is specified for the closure of the Central American Seaway, the upper $95 \%$ confidence limit for the divergence of $H$. erectus and $H$. hippocampus postdates even the most recent estimate for the spreading of the Atlantic Ocean. Likewise, if the Atlantic biome clade comprising the above species and the basally Indo-Pacific clade comprising all other species diverged as a result of Tethyan Seaway closure, then node A cannot define a western Tethyan lineage that arose at the same time (again, the upper 95\% confidence limit using the upper bound of 8.5 mya considerably postdates the most recent geological estimate for this event). Furthermore, the fact that the basal split in the seahorse phylogeny into an Atlantic Ocean lineage and a basally Indo-Pacific lineage predated all of the divergence events resulting in amphi-Atlantic distribution patterns (which could be interpreted as Tethyan Seaway closure 11.2 - 28.5 mya, and continental break-up 84 mya, respectively) suggests that none of the amphi-Atlantic distribution patterns are the result of vicariance. As none of the pairwise genetic distances between amphi-Atlantic sister lineages of other teleosts investigated were substantially greater than the distance between the two most divergent pair of seahorse lineages, we conclude that these did not diverge as a result of vicariance either. Our results thus support other recent studies on Atlantic Ocean marine organisms that identified long-distance dispersal as the cause for the establishment of amphi-Atlantic sister lineages [70,96-98].

The impression that vicariance hypotheses are increasingly being invoked to explain biogeographic patterns in the sea [12] may to some extent have been created by the increased use of molecular dating in genetic studies of marine organisms, which relies on well-documented vicariance events to use as calibration points. Founder dispersal events are less useful for this purpose, but we conclude that in the circumglobally distributed seahorse lineage, divergence events that resulted from founder dispersal are likely to outnumber divergence events that resulted from vicariance. We hypothesise that founder dispersal is thus of particular importance in species that disperse by means of rafting.

\section{Methods}

\section{Taxon sampling and sequencing}

The total sample used to reconstruct the phylogeny of the monophyletic circumglobally distributed seahorse lineage (clade 4 in Teske et al. [53]) consisted of 26 individuals from 13 species (Table 3 ). We also included a single individual each of species from the circumglobal clade's three sister lineages (clades 1, 2 and 3 in Teske et al. [53]) as outgroup taxa. We attempted to obtain tissue material from more than one specimen of each ingroup species to account for intra-specific variation. This was considered particularly important in the case of species with wide distribution ranges. The Hawai'ian seahorse that was previously referred to as Hippocampus hilonis [6] or H. fisheri [53] is correctly referred to as $H$. fisheri in this study. Morphologically, this species resembles $H$. trimaculatus (a species closely related to the outgroup species $H$. comes), suggesting that it is not part of the circumglobal clade and that specimens that group genetically with $H$. ingens are likely to be $H$. hilonis (a possible synonym of $H$. kuda, SA Lourie, pers. comm.). We have now confirmed that our Hawai'ian specimens are morphologically very different from $H$. kuda and that they fit the descripton of $H$. fisheri [62] well. All five genetic markers used in this study confirm that our specimens are the sister taxon of $H$. ingens, that they are not part of the H. kuda complex, and that they are genetically very different from $H$. trimaculatus (Fig. 2). This suggests that the morphology of $H$. fisheri was misleading.

For phylogenetic reconstruction and molecular dating, we used sequence data of three mitochondrial markers (control region, cytochrome $b$ gene and 16S rRNA) and one nuclear marker (the first intron of the S7 ribosomal protein, herafter referred to as S7 intron). Sequences of a second nuclear marker, Aldolase, were used for phylogenetic reconstructions only. Mitochondrial markers often fail to resolve deeper relationships at the taxonomic levels of family and order in various teleosts $[99,100]$, but generally provide good resolution at and below the genus level $[101,102]$. For that reason, they can be considered ideal to study the phylogeny of the circumglobal seahorse clade (one of five major genetic lineages comprising the genus Hippocampus [53]). DNA extraction and amplification of molecular markers followed previously described protocols $[43,53,103]$.

A total of 61 new sequences were generated for this study (GenBank accession numbers starting with DQ, Table 3). These were complemented with 82 previously published seahorse sequences (accession numbers starting with $\mathrm{AF}$ and AY $[6,43,52,53])$. For phylogenetic reconstructions, complete cytochrome $b$ sequences generated by Casey et al. [52] were used whenever available, which are 424 bp longer than the partial cytochrome $b$ sequences generated in this study and in Lourie et al. [43]. Aldolase sequences were obtained for a single individual of each species only. As this marker was characterized by comparatively little variation, it was not used for molecular dating.

\section{Alignments and phylogenetic reconstructions}

Sequence alignments were generated using BALI-PHY [104]. This program estimates alignment and phylogeny 
Table 3: Samples used in this study, including species names, collection localities, collectors or museums that contributed samples and GenBank accession numbers.

\begin{tabular}{|c|c|c|c|c|c|c|c|}
\hline \multirow[b]{2}{*}{ Species } & \multirow[b]{2}{*}{$\begin{array}{l}\text { Collection } \\
\text { locality }\end{array}$} & \multirow[b]{2}{*}{$\begin{array}{l}\text { Collector/ } \\
\text { Museum }\end{array}$} & \multicolumn{5}{|c|}{ GenBank accession numbers } \\
\hline & & & Control region & Cytochrome b & I6S rRNA & S7 intron & Aldolase \\
\hline \multicolumn{8}{|l|}{ Ingroup: } \\
\hline Hippocampus & Benin $(*$ Ghana $)$ & Z. Sohou, & DQ288337 & AFI92642* & AY277302 & AY277328 & AY277366 \\
\hline algiricus & Benin & *. Macpherson & DQ288338 & DQ288353 & AY277302 & AY277328 & \\
\hline H. capensis & South Africa & P. Teske & AYI49667 & AFI92650 & AY277304 & AY277331 & AY277357 \\
\hline \multirow[t]{2}{*}{ H. erectus } & $\begin{array}{l}\text { USA (Gulf of } \\
\text { Mexico) }\end{array}$ & FM & DQ288325 & AFI92662 & $\underline{\mathrm{AF} 355007}$ & $\underline{\text { AY277339 }}$ & AY277354 \\
\hline & Colombia & H. Hamilton & DQ288326 & DQ28834I & $\underline{D Q 288359}$ & DQ288378 & \\
\hline \multirow[t]{2}{*}{ H. fisheri } & Hawaii & H. Hamilton & AY642331 & DQ288350 & $\overline{\mathrm{DQ} 288369}$ & AY 277340 & AY277358 \\
\hline & Hawaii & H. Hamilton & AY642331 & DQ28835I & $\underline{\mathrm{DQ} 288370}$ & AY277340 & \\
\hline$H$. fuscus & Egypt (Red Sea) & H. Gabr & AY642337 & $\overline{\mathrm{DQ} 288354}$ & $\overline{\mathrm{DQ} 288371}$ & $\overline{\mathrm{AY} 277335}$ & AY277359 \\
\hline H. guttulatus & Italy (*Portugal) & PS, *. Curtis & DQ288322 & AFI92664 & AY277307 & AY277337 & AY27736I* \\
\hline \multirow[t]{2}{*}{ H. hippocampus } & Italy (Portugal*) & PS & DQ288323 & AFI92666 & AY277306 & AY77338 & AY277374* \\
\hline & $\begin{array}{l}\text { Israel } \\
\text { (Mediterranean } \\
\text { ) }\end{array}$ & B. Galil & DQ288324 & DQ288340 & DQ288358 & DQ288377 & \\
\hline \multirow[t]{4}{*}{$H$. ingens } & Ecuador & H. Hamilton & DQ288333 & DQ288346 & DQ288365 & DQ288383 & \\
\hline & $\begin{array}{l}\text { Mexico (East } \\
\text { Pacific) }\end{array}$ & J. Baum & AY642329 & DQ288345 & $\overline{\mathrm{DQ} 288364}$ & AY277334 & \\
\hline & Peru & PS & DQ288331 & $\mathrm{AF} 192672$ & AY 277303 & AY277333 & AY277365 \\
\hline & $\begin{array}{l}\text { USA (East } \\
\text { Pacific) }\end{array}$ & H. Hamilton & DQ288332 & DQ288344 & DQ288363 & DQ288382 & \\
\hline H. kelloggi & Vietnam & PS & AY629249 & AFI92675 & AY277298 & AY277325 & AY277350 \\
\hline \multirow[t]{4}{*}{ H. kuda } & Fiji & H. Hamilton & AY642333 & DQ288357 & DQ288374 & DQ288388 & \\
\hline & India & A. Sreepada & AY642345 & $\underline{\mathrm{AFI}} 92679$ & DQ288372 & AY277324 & AY277355 \\
\hline & Indonesia & S. Lourie & AY642356 & DQ288356 & DQ288373 & DQ288387 & \\
\hline & Philippines & M. Santos & AY 642369 & AFI92683 & DQ288375 & AY277329 & AY277356 \\
\hline \multirow[t]{3}{*}{ H. reidi } & $\begin{array}{l}\text { Brazil } \\
\text { (aquarium } \\
\text { trade) }\end{array}$ & L. Smith & DQ288336 & AFI96292 & DQ288368 & DQ288386 & \\
\hline & Honduras & H. Hamilton & DQ288335 & DQ288348 & DQ288367 & DQ288385 & \\
\hline & $\begin{array}{l}\text { USA (Gulf of } \\
\text { Mexico) }\end{array}$ & PS & $\overline{D Q 288334}$ & DQ288347 & $\overline{\mathrm{DQ} 288366}$ & $\overline{\mathrm{DQ} 288384}$ & AY227367 \\
\hline H. spinosissimus & Philippines & S. Lourie & DQ288329 & AFI92695 & AY277296 & AY277323 & AY277364 \\
\hline \multirow[t]{2}{*}{ H. zosterae } & $\begin{array}{l}\text { USA (Gulf of } \\
\text { Mexico) }\end{array}$ & FM & DQ288327 & AF35607I & $\overline{\mathrm{DQ} 288360}$ & $\overline{\mathrm{DQ} 288379}$ & AY27737I \\
\hline & $\begin{array}{l}\text { USA (Gulf of } \\
\text { Mexico) }\end{array}$ & $\mathrm{FM}$ & DQ288328 & AF35607I & DQ28836I & DQ288380 & \\
\hline \multicolumn{8}{|l|}{ Outgroup: } \\
\hline H. breviceps & Australia & AM & $\underline{D Q 288319}$ & AFI92647 & AY277287 & AY277320 & AY277342 \\
\hline H. comes & Philippines & N. Perante & DQ288321 & $\mathrm{AFI92656}$ & AY277289 & DQ288376 & AY277352 \\
\hline H. coronatus & Japan & T. Mukai & DQ288320 & AFI92658 & AY277293 & AY277319 & AY277348 \\
\hline
\end{tabular}

Sequences in boldface were used to reconstruct phylogenies. All sequences except those of Aldolase were used for molecular dating. Cytochrome $b$ sequences whose accession numbers start with $A F$ are 423 bp longer than those starting with $D Q$ and were used to reconstruct phylogenies. Control region, cytochrome $b$ and I6S rRNA are mitochondrial markers, S7 intron and Aldolase are nuclear markers. In some cases, samples from two different localities were used to represent a particular species.

FM = Florida Museum, PS = Project Seahorse, $A M=$ Australian Museum

*Collection locality, collector, and accession number of the less frequently used sample 
simultaneously in a Bayesian framework, and in this way avoids the problems associated with poor guide trees in the more widely used alignment program CLUSTALX [105]. Confidence of the results is assessed using posterior probabilites, and the indel model implemented allows indels several characters in length and also allows these to nest or overlap if they lie on separate branches. Three partitions were characterized by length differences (control region, $16 \mathrm{~S}$ rRNA and S7 intron). These were aligned individually because of computational constraints when aligning combined data-sets. Prior to generating BAli-PHY alignments, we explored which models of sequence evolution were most appropriate for each partition by generating CLUSTALX [105] alignments of ingroup sequences using default settings, and then using the Akaike information criterion [106] as implemented in MODELTEST version 3.7 [107]. As all models selected were fairly complex, we specified the most complex model presently implemented in BALI-PHY (the Tamura-Nei model [108]) for simultaneous estimation of alignment and phylogeny. A gamma distribution parameter and an assumed proportion of invariable sites were also specified if these were selected as model components by MODELTEST. For each partition aligned in BALI-PHY, 500 iterations were performed, and the final alignment was based on all alignments recovered excluding the burn-in. The procedure was repeated five times to ensure consistency of results. BALI-PHY's algorithm has very short burn-in times, and in the case of our comparatively small data-sets, convergence was complete by the tenth generation for all three partitions characterized by length differences. Maximum $a$ posteriori alignments used for further analyses were thus based on the remaining 490 iterations.

A single representative of each species was used for alignment and phylogenetic reconstruction, because exploratory alignments using the program CLUSTALX [105] followed by phylogenetic reconstructions using the neighbour-joining method [109] revealed that the geographically distant representatives of each species were monophyletic. An exception was made in the case of the Indo-Pacific species Hippocampus kuda, which was represented by one individual from India (Indian Ocean lineage) and one individual from north Sulawesi, Indonesia (West Pacific lineage). Control region sequences indicated that these two lineages may not be monophyletic and might be considered to be different species [6], a result that was, however, not strongly supported. In addition to 14 specimens representing the ingroup, we also included the three outgroup species $H$. breviceps, $H$. comes and $H$. coronatus (representatives of clades 1,2 and 3 in Teske et al. [53]). As the alignment method was strongly influenced by the presence of missing data, a section of missing data 50 bp in length in the S7 intron sequence of H. erectus was temporarily replaced with corresponding characters from its sister species H. hippocampus (the surrogate characters were removed for subsequent analyses). The sistertaxon relationship of the two species was strongly supported by previous studies $[52,53]$.

The data matrix used for phylogenetic reconstructions included the three partitions aligned using BALI-PHY, as well as three additional partitions. Firstly, complete cytochrome $b$ sequences were used, whenever available (resulting in $424 \mathrm{bp}$ of missing data in $H$. fisheri and $H$. fuscus). Secondly, indels in the three partitions that were characterized by length differences were coded as presence/absence characters in some analyses if they were present in more than one species, had a length of more than one nucleotide, and had clearly defined alignment boundaries. Thirdly, Aldolase sequences [53] were included (Table 3). These contained only two indels, each of them one nucleotide in length, and were aligned by eye. The aligned sequence lengths of control region, $16 \mathrm{~S}$ rRNA and S7 intron were 389, 532 and 596 nucleotides in length, respectively. Eight indels were coded as presence/ absence data, and cytochrome $b$ and Aldolase sequences were 1140 and 188 nucleotides in length, respectively, resulting in a total sequence length of 2853 characters.

This data matrix (excluding the partition comprising indels) was used to recover a maximum likelihood tree by generating 200 iterations of the 'likelihood ratchet' [110], which is a model-based procedure analogous to the parsimony ratchet [111]. Tree searches that employ ratcheting are less likely to become stuck on suboptimal tree islands than any other method of phylogenetic reconstruction presently available. Runs were repeated five times to ensure that the tree space was adequately explored, as indicated by the tree topology with the highest likelihood score being consistently recovered. Nodal support for this tree was obtained by means of bootstrap resampling (1000 replicates) using maximum likelihood in PAUP* version $4.0 \mathrm{~b} 10$ [112], with a single most appropriate model being specified for the whole data-set as determined using the Akaike Information Criterion in MODELTEST. The heuristic search was limited to a maximum of 10000 saved trees. Secondly, we used the heuristic parsimony analysis in PAUP* to recover the most parsimonious tree using the same data-set and including indels as presence/absence characters. Default parameters were specified, with 100 random addition replicates and 1000 trees retained at each step. Nodal support for this topology was obtained by means of jackknifing (100 000 replicates, 50\% deletion) using default parameters in PAUP* . Thirdly, MRBAYES version 3.1 [113] was used to determine posterior probabilities for each node. The Markov chain Monte Carlo process was set for four chains to run simultaneously for 2000000 generations, with trees being sampled every 100 generations. In addition to 
examining posterior probabilities of the resulting trees to determine when burn-in was complete, we also compared standard errors of posterior probabilities between simultaneous runs. As these tended to decrease for some time after the burn-in phase, only trees were used once the difference in standard errors had also stabilized (i.e. the first 4000 out of a total of 20000 trees were exluded). Bayesian analyses were repeated three times to ensure that chains had converged. We specified unique model priors for each partition as determined using MRMODELTEST version 2.2 [114]. An exception were the 16S rRNA sequences, which were aligned to the secondary structure model of the teleost Pygocentrus nattereri [115] to identify stem and loop regions, and the doublet model was invoked for complementary stem regions. Model priors from MRMODELTEST were, however, specified for stem regions for which no complementary regions were available for our partial 16S rRNA sequences, as well as for loop regions.

\section{Molecular dating}

We compared genetic divergence between seahorse lineages whose distribution patterns may have arisen as a result of the closures of the Central American, Tethyan or Indonesian seaways, or spreading of the Atlantic Ocean, with those of various other teleost lineages having the same distribution patterns. Following previous studies that estimated genetic distances of transisthmian sister species [22,23], we calculated genetic distances under the Kimura 2-Parameter (K2P) model [116]. As cytochrome $b$ and 16S rRNA sequences are most frequently used for phylogenetic reconstructions in teleosts, we limited our comparisons to these two markers.

To ensure that evolutionary rates between seahorses and other teleosts were not significantly different, we applied the relative rate test implemented in RRTREE [117]. This test takes into account phylogenetic relationships and corrects for sampling imbalances. All relative rate tests were carried out in a pairwise fashion by comparing rates in the seahorse phylogeny with rates in one of the other teleost lineages. As outgroup for each pairwise comparison, we used the bonefish Albula, as this was the only non-percomorph teleost genus investigated. In the case of cytochrome $b$, tests were performed separately for synonymous and non-synonymous substitutions by computing the parameters B4 (number of synonymous transversions per fourfold degenerate site) and Ka (number of non-synonymous substitutions per non-synonymous site), whereas the K2P substitution model was applied to the 16S rRNA data (using BALI-PHY alignments of seahorses and other teleosts that were generated as described previously). For comparison, we also plotted pairwise distances of lineages of seahorses and other teleosts that may have arisen as a result of the closures of the Indonesian and Tethyan seaways, as well as continental break-up followed by spreading of the Atlantic Ocean, by virtue of their present-day distribution patterns. Lineages characterized by different evolutionary rates than the seahorses, as well as lineages that were not tested either because different positions of a particular molecular marker were used or because they were used as outgroup for the relative rate test were also plotted for comparison, but were not considered in the analyses.

To date nodes in the seahorse phylogeny, we explored whether rate differences were present among species using RRTREE. The same three species that comprised the outgroup in phylogenetic reconstructions were also used as reference taxa in these analyses. Significant rate differences were identified in the case of three of the partitions (16S rRNA, control region and S7 intron), which prompted us to estimate the ages of divergence events among different seahorse lineages by means of the Bayesian relaxed clock method for multiple genes implemented in the programmes ESTBRANCHES and MULTIDIVTIME [58]. The maximum likelihood tree topology was specified, and to incorporate within-species differences, we included all specimens available for each species and specified phylogenetic relationships among these as unresolved polytomies. Again, the three species Hippocampus breviceps, H. coronatus and H. comes were used as outgroup taxa. MULTIDIVTIME was used to estimate the ages of divergence events and their $95 \%$ confidence intervals. The Markov chain was sampled 50000 times, with 100 cycles between each sample and a burn-in of 50 000 cycles. The process was then repeated by sampling 100000 times and specifying a burn-in of 100000 cycles. Differences in the results of these two runs would indicate that the program has not been run for sufficiently long for Markov chains to converge. This was found not to be the case (divergence time estimates differed by no more than 0.0005).

Settings of the parameters rttm, rtrate, brownian and big time followed suggestions in the MULTIDIVTIME manual. The prior expected number of time units between tip and root ( $\mathrm{rttm}$ ) was set to 22 mya (Early Miocene), as this date was between the most recent (Middle Miocene) and oldest (Late Oligocene) divergence times specified for the root node. As the value for $r t t m$ should be between 0.1 and 10 , we set it to 2.2. All subsequent values expressing time in million years were also multiplied by 0.1 .

The mean of the prior distribution for the rate at the root node (rtrate) was estimated by dividing the median of all branch lengths from root to ingroup tips by $\mathrm{rrtm}$. A value of 0.7 was specified for brownian, as brownian multiplied by $\mathrm{rttm}$ should be between 1 and $2(2.2 \times 0.7=1.5)$. The highest possible number of time units between tip and 
root (big time) was set to 50 (i.e. 500 million years). The magnitude of standard errors was set equal to that of each of the parameters $\mathrm{rttm}$, rtrate and brownian. We examined the effect of the choice of parameter priors on divergence time estimates by doubling all of them. The fact that time estimates obtained in this way differed by no more than 0.1 (1 million years; mean difference: 0.03 or 300000 years) suggests that the choice of priors had little effect on time estimates.

Molecular dating was done in two ways. Firstly, to date divergence events that may have resulted from vicariance events, we specified only the well-documented closure of the Central American Seaway as a calibration point and specified three alternative calibration ranges for the timing of this event: a) 3.1 - 3.5 mya [19], i.e. assuming that the divergence of the transisthmian seahorse lineages took place during the final closure of the seaway; b) $3.1-4.6$ mya, with the upper limit representing the onset of a marked reorganization of ocean circulation in Central America that was associated with the rising of the Isthmus of Panama [35], and c) $3.1-8.5$ mya, to account for the possibility that seahorses were affected by the earliest possible evolution associated with the closure of the seaway [26]. Secondly, we dated all nodes in the phylogeny by using a well-supported divergence range of the transisthmian seahorse lineages in combination with other divergence events whose divergence time estimates matched the timing of vicariance events suggested in the literature in the first analysis.

\section{Authors' contributions}

PRT designed the study, obtained the majority of the samples, carried out the laboratory work, did the analyses and prepared the manuscript. HH provided additional samples and helped with the laboratory work. CAM and NPB participated in the design of the study and contributed to the preparation of the manuscript. All authors read and approved the final version.

\section{Acknowledgements}

We are grateful to Sara Lourie, Bella Galil, Zacharie Sohou, Melchor Santos, Howaida Gabr, Anantha Sreepada, Takahiko Mukai, Leo Smith, Janelle Curtis, as well as the Australian Museum and the Florida Museum of Natural History, for contributing samples. Thanks also to Bob Wynn Jones, Giacomo Bernardi, John Whittaker, John McManus, Johnathan Kool, Carel van Heerden, Yusuf Motara and Ryuichi Tsuchi for their contributions, and to Bronwyn McLean (Rhodes University Graphics Services Unit) for compiling the map. Syd Ramdhani, Nicolas Devos, Roderic Page, Adrian Paterson, Jonathan Waters and six anonymous reviewers are thanked for their comments on earlier versions of the manuscript. This study was supported by a Claude Harris Leon postdoctoral research fellowship and a Harry Crossley Foundation ex gratia bursary awarded to PRT, a grant from the National Research Foundation to NPB (GUN20691 19), and Stellenbosch University.

\section{References}

I. Croizat L: Panbiogeography Volume 3. Caracas: Published by the author; 1958.

2. Darwin C: On the origin of species by means of natural selection or the preservation of favoured races in the struggle for life London: Murray; 1859.

3. Wallace AR: On the zoological geography of the Malay Archipelago. Proc Linn Soc London I860, 4:173-I84.

4. Mayr E: Animal species and evolution Harvard University Press, MA; 1963.

5. de Queiroz A: The resurrection of oceanic dispersal in historical biogeography. Trends Ecol Evol 2005, 20:68-73.

6. Teske PR, Hamilton H, Palsbøll PJ, Choo CK, Gabr H, Lourie SA, Santos M, Sreepada A, Cherry MI, Matthee CA: Molecular evidence for long-distance colonization in an Indo-Pacific seahorse lineage. Mar Ecol Prog Ser 2005, 286:249-260.

7. Perante NC, Pajaro MG, Meeuwig JJ, Vincent ACJ: Biology of a seahorse species, Hippocampus comes in the central Philippines. J Fish Biol 2002, 60:82 I-837.

8. Kuiter RH: Seahorses, pipefishes and their relatives - a comprehensive guide to Syngnathiformes TMC Publishing, Chorleywood, UK; 2000.

9. Holmquist JG: Benthic macroalgae as a dispersal mechanism for fauna: influence of a marine tumbleweed. J Exp Mar Biol Ecol 1994, | 80:235-251.

10. Foster SJ, Vincent ACJ: Life history and ecology of seahorses: implications for conservation and management. J Fish Biol 2004, 65:|-6I.

II. Welch JJ, Bromham L: Molecular dating when rates vary. Trends Ecol Evol 2005, 20:320-327.

12. Heads M: Towards a panbiogeograpy of the seas. Biol J Linn Soc 2005, 84:675-723.

13. Heads M: Dating nodes on molecular phylogenies: a critique of molecular biogeography. Cladistics 2005, 2 I:62-78.

14. Ridgway SA, Reid DG, Taylor JD, Branch GM, Hodgson AN: A cladistic phylogeny of the family Patellidae (Mollusca: Gastropoda). Phil Trans R Soc B 2003, 353:1645-I67I.

15. Dzik J: The chronophyletic approach: stratophenetics facing an incomplete fossil record. Spec Pap Palaeont 2005, 73: I59-I83.

16. Sorbini L: Biogeography and climatology of Pliocene and Messinian fossil fish of Eastern Central Italy. Boll Mus Civ Stor Natur Verona 1988, 14: |-85.

17. Zalohar J, Hitij T, Kriznar M: The oldest fossil seahorses found in Slovenia. GEA 2006, 16:52-55.

18. Keigwin LD: Pliocene closing of the isthmus of Panama based on biostratigraphic evidence from nearby Pacific and Caribbean sea cores. Geology 1978, 6:630-634.

19. Duque-Caro H: Neogene stratigraphy, palaeoceanography, and palaeobiology in northwestern South America and the evolution of the Panama seaway. Palaeogr Palaeoclimatol Palaeoecol 1990, 777:203-234.

20. Coates AG, Jackson JBC, Collins LS, Cronin TM, Dowsett HJ, Bybell LM, Jung P, Obando J: Closure of the Isthmus of Panama: The near-shore marine record of Costa Rica and western Panama. Geol Soc Am Bull 1992, 1 04:814-828.

21. Bermingham E, McCafferty SS, Martin AP: Fish biogeography and molecular clocks: perspectives from the Panamanian isthmus. In Molecular systematics of fishes Edited by: Kocher TD. Stepien Academic Press, New York; 1997:I I3-I 28.

22. Knowlton N, Weigt LA: New dates and new rates for divergence across the Isthmus of Panama. Proc Roy Soc B 1998 , 265:2257-2263

23. Tringali MD, Bert TM, Seyoum S, Bermingham E, Bartolacci D: Molecular phylogenetics and ecological diversification of the transisthmian fish genus Centropomus (Perciformes: Centropomidae). Mol Phylogenet Evol 1999, I 3:193-207.

24. Marko PB: Fossil calibration of molecular clocks and the divergence times of geminate species pairs separated by the Isthmus of Panama. Mol Biol Evol 2002, I 9:2005-202I.

25. Haug $\mathrm{HH}$, Tiedemann R: Effect of the formation of the Isthmus of Panama on Atlantic Ocean thermohaline circulation. Nature 1998, 393:673-676.

26. Collins LS, Budd AF, Coates AG: Earliest evolution associated with the Tropical American Seaway. Proc Natl Acad Sci USA 93:6069-6072.

27. Craig MT, Hastings PA, Pondella DJ II: Speciation in the Central American seaway: the importance of taxon sampling in the 
identification of trans-isthmian geminate pairs. J Biogeogr 2004, 3 I:|085-109|.

28. Bowen W, Bass AL, Rocha LA, Grant WS, Robertson DR: Phylogeography of the trumpetfishes (Aulostomus): ring species complex on a global scale. Evolution 200I, 55:1029-1039.

29. Lessios HA, Kessing BD, Pearse JS: Structure and speciation in tropical seas: global phylogeography of the sea urchin Diadema . Evolution 200I, 55:995-975.

30. Hrbek T, Meyer A: Closing of the Tethys Sea and the phylogeny of Eurasian killifishes (Cyprinodontiformes: Cyprinodontidae). J Evol Biol 2003, 16:7-26.

31. Barber PH, Bellwood DR: Biodiversity hotspots: evolutionary origins of biodiversity in wrasses (Halichoeres : Labridae) in the Indo-Pacific and New World tropics. Mol Phylogenet Evol 2005, 35:235-253

32. Drooger CW: Marine connections of the Neogene Mediterranean deduced from the evolution and distribution of larger Foraminifera. Ann Geol D Pays Hell 1979, 1979:36I-369.

33. Adams CG, Gentry AW, Whybrow PJ: Dating the terminal Tethyan event. In Reconstruction of marine environments Edited by: Meulenkamp J. Utrecht Micropalaeontological Bulletins; 1983:273-298.

34. Adams CG, Lee DE, Rosen BR: Conflicting isotopic and biotic evidence for tropical sea-surface temperatures during the Tertiary. Palaeogeogr Palaeoclimatol Palaeoecol 1990, 77:289-313.

35. Rögl F, Steininger FF: Vom Zerfall der Tethys zu Mediterran und Paratethys. Ann Naturhist Mus Wien 1983, 85: I35-163.

36. Rög| F, Steininger FF: Neogene Paratethys, Mediterranean and Indo-Pacific Seaways. In Fossils and Climate Edited by: Brenchley P. John Wiley, New York; 1984:I7I-200.

37. Adams CG, Bayliss DD, Whittaker JEP: The terminal tethyan event: a critical review of the conflicting age determinations for the disconnection of the Mediterranean from the Indian Ocean. In Fossil vertebrates of Arabia Edited by: Whybrow PJ, Hill A. Yale University Press, New Haven; 1999:477-484.

38. Jones RW: Marine invertebrate (chiefly foraminiferal) evidence for the palaeogeography of the Oligocene-Miocene of western Eurasia, and consequences for terrestrial vertebrate migration. In Hominid evolution and climatic change in Eurasia, Climatic and environmental change in the Neogene of Europe Volume I. Edited by: Agusti J, Rook L, Andrews P. Cambridge University Press; 1999:274-308

39. McMillan WO, Palumbi SR: Concordant evolutionary patterns among Indo-West Pacific butterflyfishes. Proc $R$ Soc B 1995 , 260:229-236.

40. Barber PH, Palumbi SR, Erdmann MV, Moosa MK: Sharp genetic breaks among populations of Haptosquilla pulchella (Stomatopoda) indicate limits to larval transport: patterns, causes, and consequences. Mol Ecol 2002, I I:659-674.

4I. Williams ST, Jara J, Gomez E, Knowlton N: The marine Indo-West Pacific break: contrasting the resolving power of mitochondrial and nuclear genes. Integr Comp Biol 2002, 42:941-952.

42. Kochzius M, Söller R, Khalaf MA, Blohm D: Molecular phylogeny of the lionfish genera Dendrochirus and Pterois (Scorpaenidae, Pteroinae) based on mitochondrial DNA sequences. Mol Phylogenet Evol 2003, 28:396-403.

43. Lourie SA, Green DM, Vincent ACl: Dispersal, habitat differences, and comparative phylogeography of Southeast Asian seahorses (Syngnathidae: Hippocampus). Mol Ecol 2005 , 14:1073-1094.

44. Nishimura S, Suparka S: Tectonic approach to the Neogene evolution of Pacific-Indian Ocean seaways. Tectonophysics 1997 28I:I-16.

45. Gasperi JT, Kennett JP: Vertical thermal structure evolution of Miocene surface waters: western equatorial Pacific DSDP Site 289. Mar Micropaleont 1993, 22:235-254.

46. Linthout K, Helmers H, Sopaheluwakan J: Late Miocene obduction and microplate migration around the southern Banda Sea and the closure of the Indonesian Seaway. Tectonophysics 1997, 28I: $17-30$.

47. Cane MA, Molnar P: Closing of the Indonesian seaway as a precursor to east African aridification around 3-4 million years ago. Nature 200I, 4I I:I57-162.

48. McManus JW: Marine speciation, tectonics and sea-level changes in southeast Asia. Proc 5th Int/ Coral Reef Congr 1985, 4:133-138.
49. Voris HK: Maps of Pleistocene sea levels in Southeast Asia: shorelines, river systems and time duration. J Biogeogr 2000, 27:1153-1167.

50. Rosen DM: A vicariance model of Caribbean biogeography. Syst Zool 1975, 24:43 I-464

5I. Pittman WC III, Cande S, LaBrecque J, Pindell J: Fragmentation of Gondwana: the separation of Africa from South America. In Biological relationships between Africa and South America Edited by: Goldblatt P. Yale University Press, New Haven, CT; 1993:I5-34.

52. Casey SP, Hall HJ, Stanley HF, Vincent ACJ: The origin and evolution of seahorses (genus Hippocampus): a phylogenetic study using the cytochrome $b$ gene of mitochondrial DNA. Mol Phylogenet Evol 2004, 30:26I-272.

53. Teske PR, Cherry MI, Matthee CA: The evolutionary history of seahorses (Syngnathidae: Hippocampus): molecular data suggest a West Pacific origin and two invasions of the Atlantic Ocean. Mol Phylogenet Evol 2004, 30:273-286.

54. Teske PR, Lourie SA, Matthee CA, Green DM: Hippocampus queenslandicus Horne, $200 \mathrm{I}-\mathrm{a}$ new seahorse species or yet another synonym? Aust J Zool 2007, 55:|39-| 45.

55. Nelson G, Platnick N: Systematics and Biogeography: Cladistics and Vicariance Columbia University Press; 198I.

56. Cook LG, Crisp MD: Directional asymmetry of long-distance dispersal and colonization could mislead reconstructions of biogeography. J Biogeogr 2005, 32:74I-754.

57. Burridge CP, Roberto MC, Dyer BS: Muliple origins of the Juan Fernández kelpfish fauna and evidence for frequent and unidirectional dispersal of cirrhitoid fishes across the South Pacific. Syst Biol 2006, 55:566-578.

58. Thorne JL, Kishino $\mathrm{H}$ : Divergence time and evolutionary rate estimation with multilocus data. Syst Biol 2002, 5 I:689-702.

59. Yang Z, Yoder AD: Comparison of likelihood and Bayesian methods for estimating divergence times using multiple gene loci and calibration points, with application to radiation of cute-looking mouse lemur species. Syst Biol 2003, 52:705-716.

60. Schubart CD, Diesel R, Hedges SB: Rapid evolution to terrestrial life in Jamaican crabs. Nature 1998, 393:363-365.

61. Bellwood DR, van Herwerden L, Konow N: Evolution and biogeography of marine angelfishes (Pisces: Pomacanthidae). Mol Phylogenet Evol 2004, 33: 140-155.

62. Lourie SA, Foster SJ, Cooper EWT, Vincent ACJ: A Guide to the Identification of Seahorses Project Seahorse and TRAFFIC North America. Washington D.C.: University of British Columbia and World Wildlife Fund; 2004

63. Knowlton N: Sibling species in the sea. Ann Rev Ecol Syst 1993, 24:189-216

64. Cronin TM, Dowsett $\mathrm{H}$ ]: Biotic and oceanographic response to the Pliocene closing of the Central American isthmus. In Evolution and environment in tropical America Edited by: Jackson JBC, Coates AG. University of Chicago Press, Chicago, II; 1996:76-104.

65. Brown WM: Evolution of animal mitochondrial DNA. In Evolution of genes and proteins Edited by: Nei M, Koehn RK. Sinauer, Sunderland, MA; 1983:62-88.

66. Wilson BA, Ahnesjö I, Vincent ACJ, Meyer A: The dynamics of male brooding, mating patterns, and sex roles in pipefishes and seahorses (Family Syngnathidae). Evolution 2003, 57:1374-1386.

67. Benton MJ: The Fossil Record Chapman \& Hall, London; 1993.

68. Kaneps AG: Gulf Stream: velocity fluctuations during the late Cenozoic. Science 1979, 204:297-30I.

69. Keller G, Barron JA: Palaeoceanographic implications of Miocene deep-sea hiatures. Geol Soc Am Bull 1983, 97:590-613.

70. Bernardi G, Robertson DR, Clifton KE, Azzurro E: Molecular systematics, zoogeography and evolutionary ecology of the Atlantic parrotfish genus Sparisoma. Mol Phylogenet Evol 2000, I5:292-300.

7I. Joyeux J-C, Floeter SR, Ferreira CEL, Gasparini JL: Biogeography of tropical reef fishes: the South Atlantic puzzle. J Biogeogr 200I, 28:83I-84I.

72. Muss A, Robertson DR, Stepien CA, Wirtz P, Bowen BW: Phylogeography of Ophioblennius: the role of ocean currents and geography in reef fish evolution. Evolution 200I, 55:56I-572.

73. Luiz-Júnior OJ, Floeter SR, Gasparini JL, Ferreira CEL, Wirtz P: The occurrence of Acanthurus monroviae (Perciformes:Acanthuridae) in the south-western Atlantic, with comments on 
other eastern Atlantic reef fishes occurring in Brazil. J Fish Biol 2004, 65: II73-II79.

74. Randall JE: Zoogeographic analysis of the inshore Hawaiian fish fauna. In Marine and coastal biodiversity in the tropical island Pacific Ocean, Species systematics and information managenement priorities Volume I. Edited by: Maragos JE, Eldredge MNA, Bardach JE, Takeuchi HF. Honolulu: Pacific Science Association, Bishop Museum 1995:193-203

75. De Grave S: Biogeography of the Indo-Pacific Pontoniinae (Crustacea, Decapoda): a PAE analysis. J Biogeogr 200I, 28:1239-1253.

76. Lessios HA, Robertson DR: Crossing the impassable: genetic connections in $\mathbf{2 0}$ reef fishes across the eastern Pacific barrier. Proc Roy Soc B 2006, 273:2201-2208.

77. Sparks JS: Molecular phylogeny and biogeography of the Malagasy and South Asian cichlids (Teleostei: Perciformes: Cichlidae). Mol Phylogenet Evol 2004, 30:599-6I4

78. Sparks JS, Smith WL: Phylogeny and biogeography of cichlid fishes (Teleostei: Perciformes: Cichlidae). Cladistics 2005, 20:50I-5I7.

79. Lessios HA, Kessing BD, Robertson DR: Massive gene flow across the world's most potent marine biogeographic barrier. Proc $R$ Soc B 1998, 265:583-588.

80. Briggs JC: Global biogeography Volume 14. Developments in paleontology and stratigraphy, Elsevier, Amsterdam; 1995.

81. Hardin G: The competitive exclusion principle. Science 1960 | 3 1:1292-1297.

82. Begon M, Harper JL, Townsend CR: Ecology Blackwell Science, Oxford; 1996.

83. Levine JM: Species diversity and biological invasions: relating local processes to community pattern. Science 2000 288:852-854.

84. Lyons KG, Schwartz MW: Rare species loss alters ecosystem function - invasion resistence. Ecol Lett 200I, 4:358-365.

85. Stachowicz JJ, Whitlatch RB, Osman RW: Species diversity and invasion resistance in a marine ecosystem. Science 1999 286: I577-I579.

86. Stachowicz JJ, Fried H, Osman RW, Whitlatch RB: Biodiversity, invasion resistance, and marine ecosystem function: reconciling pattern and process. Ecology 2002, 83:2575-2590.

87. Lodge DM: Biological invasions: lessons for ecology. Trends Ecol Evol 1993, 8: 133-137.

88. Lounibos LP, O'Meara GF, Nishimura N, Escher RL: Interactions with native mosquito larvae regulate the production of Aedes albopictus from bromeliads in Florida. Ecol Entomol 2003, 28:55I-558.

89. Sher AA, Marshall DL, Gilbert SA: Competition between native Populus deltoides and invasive Tamarix ramosissima and the implications for reestablishing flooding disturbance. Cons Biol 2000, I 4: I744-1754.

90. Byers JE: Competition between two estuarine snails: implications for invasions of exotic species. Ecology 2000, 8I:1225-1239.

91. Elton C: The ecology of invasions by animals and plants Methuen, London, UK; 1958

92. Curtis JMR, Vincent $A C$ J: Distribution of sympatric seahorse species along a gradient of habitat complexity in a seagrassdominated community. Mar Ecol Progr Ser 2005, 29 I:8I-91.

93. Hockey PAR, van Erkom Schurink C: The invasive biology of the mussel Mytilus galloprovincialis on the southern African coast. Trans R Soc S Afr 1992, 48: $123-140$.

94. Laferty K, Kuris A: Biological control of marine pests. Ecology 1996, 77:1989-2000.

95. Yamada SB: Global invader: the European green crab Oregon Sea Grant, Corvallis; 200I.

96. Wares JP, Cunningham CW: Phylogeography and historical ecology of the North Atlantic intertidal. Evolution 200I. 55:2455-2469.

97. Banford HM, Bermingham E, Collette BB: Molecular phylogenetics and biogeography of transisthmian and amphi-Atlantic needlefishes (Belonidae: Strongylura and Tylosurus): perspectives on New World marine speciation. Mol Phylogenet Evol 2004, $31: 833-851$.

98. Robertson DR, Karg F, Leao de Moura R, Victor BC, Bernardi G: Mechanisms of speciation and faunal enrichment in Atlantic parrotfishes. Mol Phylogenet Evol 2006, 40:795-807.
99. Ortí G, Meyer A: The radiation of characiform fishes and the limits of resolution of mitochondrial ribosomal DNA sequences. Syst Biol 1997, 46:75-100.

100. Farias IP, Ortí G, Sampaio I, Schneider H, Meyer A: The cytochrome $b$ gene as a phylogenetic marker: the limits of resolution for analyzing relationships among cichlid fishes. J Mol Evol 200I, 53:89-103.

10I. Rocha-Olivares A, Rosenblatt RH, Vetter RD: Molecular evolution, systematics, and zoogeography of the rockfish subgenus Sebastomus (Sebastes, Scorphaenidae) based on mitochondrial cytochrome $b$ and control region sequences. Mol Phylogenet Evol 1999, I I:44 I-458.

102. Lovejoy NR, Araújo MLG: Molecular systematics, biogeography, and population structure of Neotropical freshwater needlefishes of the genus Potamorraphis. Mol Ecol 2000, 9:259-268.

103. Teske PR, Cherry MI, Matthee CA: Population genetics of the endangered Knysna seahorse, Hippocampus capensis . Mol Ecol 2003, I 2: 1703-1705.

104. Redeling BD, Suchard MA: Joint Bayesian estimation of alignment and phylogeny. Syst Biol 2005, 54:40 I-4I8.

105. Thompson JD, Gibson TJ, Plewniak F, Jeanmougin F, Higgins DG: The CLUSTALX windows interface: flexible strategies for multiple sequence alignment aided by quality analysis tools. Nucl Acids Res 1997, 24:4876-4882.

106. Akaike $\mathrm{H}$ : Information theory as an extension of the maximum likelihood principle. In Second International Symposium on Information Theory Edited by: Petrov BN, Csaki F. Akademiai Kiado, Budapest; 1973:267-28I.

107. Posada D, Crandall KA: Modeltest: testing the model of DNA substitution. Bioinformatics 1998, | 4:817-818.

108. Tamura K, Nei M: Estimation of the number of nucleotide substitutions in the control region of mitochondrial DNA in humans and chimpanzees. Mol Biol Evol 1993, 10:5 12-526.

109. Saitou N, Nei M: The neighbour-joining method: a new method for reconstructing phylogenetic tree. Mol Biol Evol 1987, 4:406-425.

I I0. Sikes DS, Lewis PO: PAUPRAT version I. PAUP* implementation of the parsimony ratchet Distributed by the authors. Department of Ecology and Evolutionary Biology, University of Connecticut, Storrs, USA; 2001

III. Nixon KC: The parsimony ratchet, a new method for rapid parsimony analysis. Cladistics 1999, 15:407-414.

112. Swofford DL: PAUP*: Phylogenetic Analysis Using Parsimony (*and Other Methods), Version 4.0 beta 10 Sinauer Associates, Sunderland, Massachusetts; 2002.

113. Huelsenbeck JP, Ronquist F: MRBAYES: Bayesian inference of phylogeny. Bioinformatics 200I, 17:754-755.

114. Nylander JAA: MRMODELTEST V2 Program distributed by the author. Evolutionary Biology Centre, Uppsala University; 2004.

I I5. Ortí G, Petry P, Porto JIR, Jégu M, Meyer A: Patterns of nucleotide change in mitochondrial ribosomal RNA genes and the phylogeny of piranhas. J Mol Evol 1996, 42:169-182.

116. Kimura M: A simple method for estimating evolutionary rate of base substitutions through comparative studies of nucleotide sequences. I Mol Evol 1980, 16: I I - I20

II7. Robinson-Rechavi M, Huchon D: RRTREE: Relative-rate tests between groups of sequences on a phylogenetic tree. Bioinformatics 2000, 16:296-297.

1 18. Reed DL, de Gravelle MJ, Carpenter KE: Molecular systematics of Selene (Perciformes: Carangidae) based on cytochrome $b$ sequences. Mol Phylogenet Evol 200I, 2 I:468-475.

1 19. Lo Galbo AM, Carpenter KE, Reed DL: Evolution of trophic types in emperor fishes (Lethrinus, Lethrinidae, Percoidei) based on cytochrome b gene sequence variation. J Mol Evol 2002, 54:754-762

120. Bernardi G, Bucciarelli G, Costagliola D, Robertson DR, Heiser JB: Evolution of coral reef fish Thalassoma spp. (Labridae). I. Molecular phylogeny and biogeography. Mar Biol 2004, I 44:369-375.

12I. Colborn J, Crabtree RE, Shaklee JB, Pfeiler E, Bowen BW: The evolutionary enigma of bonefishes (Albula spp): cryptic species and ancient separations in a globally distributed shorefish. Evolution 200I, 55:807-820.

122. Chen WJ, Bonillo C, Lecointre G: Repeatability of clades as a criterion of reliability: a case study for molecular phylogeny of 
Acanthomorpha (Teleostei) with larger number of taxa. Mol Phylogenet Evol 2003, 26:262-288.

123. Smith WL, Wheeler WC: Polyphyly of the mail-cheeked fishes (Teleostei: Scorpaeniformes): evidence from mitochondrial and nuclear sequence data. Mol Phylogenet Evol 2004, 32:627-646.

124. Inoue JG, Miya M, Tsukamoto K, Nishida M: Mitogenomic evidence for the monophyly of elopomorph fishes (Teleostei) and the evolutionary origin of the Leptocephalus larva. Mol Phylogenet Evol 2004, 32:274-286.

Publish with Bio Med Central and every scientist can read your work free of charge

"BioMed Central will be the most significant development for disseminating the results of biomedical research in our lifetime."

Sir Paul Nurse, Cancer Research UK

Your research papers will be:

- available free of charge to the entire biomedical community

- peer reviewed and published immediately upon acceptance

- cited in PubMed and archived on PubMed Central

- yours - you keep the copyright 